\title{
5.
}

\section{Multimethod Analyses of Roman Sarcophagi at the Museo Nazionale Romano, Rome}

\author{
Frances Van Keuren, Donato Attanasio, John J. Herrmann, Jr., \\ Norman Herz, L. Peter Gromet
}

\section{Analytical Method}

In the fall of 2007 and the spring of 2008, 27 marble chips from 20 sarcophagi at the Museo Nazionale Romano in the Baths of Diocletian, Rome (hereafter MNR), were analysed, in order to determine the provenances of their marbles. ${ }^{1}$ (The Report is presented here as Appendix 1, with supporting graphs and tables, at the end of this article.) Dr. Donato Attanasio from the Istituto di Struttura della Materia, the Consiglio Nazionale delle Ricerche, Rome, first determined the colour and the maximum grain size (MGS) of each sample. He then conducted Electron Paramagnetic Resonance (EPR) analyses of the samples. Next, stable isotope analyses were carried out by Julia Cox at the Stable Isotope Laboratory of the University of Georgia Department of Geology, Athens, Georgia. Finally, Dr. Attanasio used the six resultant variables - the colour and MGS of the marble chips, the intensity and linewidth obtained from the EPR analyses, and the oxygen and carbon ratios obtained from the stable isotope analyses - to determine quarry assignments for the 20 sarcophagi. These assignments were achieved by running the data of the six variables through statistical commercial software (STATISTICA 7.1 and SPSS 13.0).

\section{Process and Explanation of Analytical Techniques}

The first step in the analyses of the 20 sarcophagi at the Museo Nazionale Romano was for Dr. Attanasio to chisel off small marble chips from the back surfaces of the chests and lids of the sarcophagi under investigation. He then took the samples to his laboratory.

1 All but one of the sarcophagi are in the Michelangelesque cloister, commonly referred to as the Chiostro Grande. The exception is a sarcophagus with Medea (Figure 5.3), located in Aula VI of the same museum. 
To determine the colour of each marble sample, the surface of each chip was polished. Then a digital scan of this polished surface was taken at 300 or 600 dpi (dots per inch) resolution. Using a Kodak grey scale with the aid of Adobe Photoshop, the colour value of each pixel was measured on an 8-bit scale (black $=0$, white $=255)$ and then used to obtain the average colour value of the sample. $^{2}$

Then, to determine the maximum grain size of each chip, Dr. Attanasio treated the already polished surface for 30 seconds with dilute hydrochloric acid $(\mathrm{HCl} 2 \mathrm{~N})$. The acid was applied to 'display the edges of the crystalline grains more clearly.' ${ }^{3}$ The largest grains were then measured using 'a normal reflecting microscope. ${ }^{4}$

Next, Dr. Attanasio detached part of the marble chip, about $30 \mathrm{mg}$., and finely ground it in an agate mortar and then weighed [it] within a normal quartz EPR tube (internal diameter $2.8-2.9 \mathrm{~mm}$ ), to a precision of $0.1 \mathrm{mg}$. ${ }^{5}$

Each sample was then placed in 'a cavity resonator placed at the centre of the field poles of an electromagnet ... which is connected to another two fundamental components of the spectrometer: the microwave source (usually a klystron) and a detector for measuring the obtained signals ... The sample within the cavity is irradiated with microwaves of a known constant frequency ... Scanning of the magnetic field then takes place and when the value of $\mathrm{H}_{0}$ [the external magnetic field] reaches the resonance value ... absorption of energy by the sample occurs, the system goes into a state of imbalance and a signal that is presented as a spectrum reaches the detector. ${ }^{36}$ Dr. Attanasio explains that 'the resonance condition consists of irradiating the sample with electromagnetic waves of a suitable frequency such that a transition from the lowest to the highest level [of energy] is induced. This can be seen as a reversal from an antiparallel to a parallel orientation (spin-flip) and the change of the direction of rotation (spin) of the electron. ${ }^{7}$

The spectrum that is obtained from inducing a resonance state in the sample is usually given in the form of what are called first derivative curves. They consist of a series of peaks and valleys, oriented along a central line. It is the spectrum of the element manganese $\left(\mathrm{Mn}^{2+}\right)$ that $\mathrm{Dr}$. Attanasio examined. $\mathrm{Mn}^{2+}$ is a magnetic impurity that occurs in all marbles, but there are variations between quarries in 'the type and arrangement of atoms that are found around the manganese ions.' These variations 'depend on the particular type of material

\footnotetext{
2 Attanasio 2003, 99.

3 Attanasio 2003, 97.

4 Attanasio 2003, 97.

5 Attanasio 2003, 82.

6 Attanasio 2003, 62 and 79.

7 Attanasio 2003, 62.
} 
and on its provenance. ${ }^{8}$ Two aspects of the $\mathrm{Mn}^{2+}$ are studied - the intensity or concentration of the manganese and the linewidth, or the temporal extent of the resonance condition. Table 1 in Dr. Attanasio's report in Appendix 1 gives the intensities and linewidths that were obtained for the 27 samples under investigation, and Graph 4 plots the logarithms of these intensities and linewidths.

The presence of manganese in marble goes back to the conditions of formation of marble's protolith, limestone. Nicholas E. Pingitore, Jr. explains what limestone is composed of, how it is lithified, and how manganese infiltrates it:

Typically composed of the skeletal remnants of marine organisms, ${ }^{9}$ most limestones are lithified by exposure to fresh water. This transition from carbonate sediment to limestone rock comes about through changes in texture, mineralogy, and chemistry of the sedimentary particles. Mineralogic stabilisation is accompanied by changes in minor and trace elements ... [Manganese $\left(\mathrm{Mn}^{2+}\right)$ has] the proper charge and ionic radii to substitute freely for calcium in the calcite lattice. ${ }^{10}$

Subsequent to lithification, limestone is metamorphosed into marble, through heat and pressure. Both limestone and marble are most commonly composed of the mineral calcite (calcium carbonate). However, they can also be composed of the mineral dolomite (calcium-magnesium carbonate; see below for a discussion of dolomitic marble from Cape Vathy, Thasos). ${ }^{11}$

After determining the colour and MGS, and conducting the EPR analyses of parts of the 27 marble chips, Dr. Attanasio mailed what remained of the chips to the laboratory maintained by Julia Cox in Athens, Georgia. She then determined the stable isotopes of the samples.

The geological definition for isotopes is that they are atoms of the same element, which have both shared and different features. What is the same in isotopes is the number of positively-charged protons. Isotopes differ in their number of uncharged neutrons, and hence in their weights. The reason quarries can be differentiated by their stable isotope structures is that the limestone protoliths were formed under slightly different conditions. According to Scott Pike, 'the isotopic composition of a marble's limestone protolith is principally controlled by crystallisation temperature, chemical composition and the isotopic ratios of the water. ${ }^{12}$ When limestone protoliths are metamorphosed into

8 Attanasio 2003, 57, 60 and 81 .

9 Other types of limestone were formed biogenically, i.e. with microorganisms, and chemically. Email from Norman Herz of October 22, 2008; and Herz 1988, 235-236.

10 Pingitore 1978, 799-800.

11 Herz and Garrison 1998, 200; Tykot et al. 2002, 189.

12 This quotation was supplied to me by Prof. Pike from his unpublished dissertation; Pike 2000. See also Herz 1988, 235-236. 
marbles, the marbles preserve the isotopic structures of their protoliths. However, Norman Herz notes that when limestone is in the process of metamorphosis, there can be additional alterations to its isotopic structure. He observes that 'the higher the temperature [of metamorphosis] the lower the ${ }^{18} \mathrm{O} .{ }^{13}$

There are stable, i.e. non-radioactive, and unstable, i. e. radioactive isotopes. The stable isotopes that are analysed or counted in an isotopic analysis of a marble sample are Carbon 12 and Carbon 13, and Oxygen 16 and Oxygen 18. Carbon 12 has 6 protons and 6 neutrons, while Carbon 13 has 6 protons and 7 neutrons. Oxygen 16 has 8 protons and 8 neutrons, and Oxygen 18 has 8 protons and 10 neutrons. Carbon 12 and Oxygen 16, the lighter isotopes, are far more abundant in nature than Carbon 13 and Oxygen 18, the heavier isotopes.

Ms. Cox's first step in the stable isotope analyses was to prepare each sample. She drilled off a small quantity of marble dust from each chip. Less than $5 \mathrm{mg}$. of material are needed to conduct an isotopic analysis. ${ }^{14}$ The second step in the analysis process was to dissolve the sample in acid. This converts the carbon and oxygen isotopes into molecules of carbon dioxide gas, or CO2. The carbon dioxide gas was then ionized, which involves the stripping of an electron from each molecule, and a resultant positive charge.

These ionized gas molecules were then accelerated towards a negative charge at the end of a tube within a mass spectrometer. The tube was magnetized. The magnet deflected or altered the course of the gas molecules. A molecule with light isotopes of carbon and/or oxygen was deflected more than a molecule with heavy isotopes of the same element(s). Collectors located at different positions at the end of the flight tube counted the molecules with the differing weights. ${ }^{15}$ From the six different possible weights of the $\mathrm{CO} 2$ molecules, the types and numbers of isotopes were calculated. For example, a molecule with a weight of 44 would contain one Carbon 12 isotope and two Oxygen 16 isotopes.

The resultant counts of the carbon and oxygen isotopes allowed specific ratios to be determined. One ratio expressed the proportion of Carbon 13 versus Carbon 12 isotopes, and the other expressed the proportion of Oxygen 18 versus Oxygen 16 isotopes. These carbon and oxygen ratios from each sample were then related to the ratios of the same isotopes from a standard. A delta number expressed the difference in abundance of the heavy isotope in each sample, in relation to the abundance of that isotope in the standard. The delta number is like a percentage difference, except that it is expressed in parts per thousand rather than in parts per hundred.

13 Email of October 22, 2008.

14 Herz and Garrison 1998, 273.

15 Herz and Garrison 1998, 273. 
Table 1 from Dr. Attanasio's report (in Appendix 1) provides the delta numbers that Ms. Cox obtained through her stable isotope analyses of the 27 samples, and Graphs 2-3 locate the points corresponding to these delta numbers. The vertical axis on the two graphs provides the location for the Carbon 13 number, and the horizontal axis supplies the location of the Oxygen 18 number.

Besides plotting the 27 samples, the two graphs include ellipses that indicate the distribution of the isotopic data for some of these ancient quarries - Afyon [Afy], Carrara [Ca], Ephesos (Kusini Tepe [Eph/KT], Belevi [Eph/BG], Aya Klikiri), Hymettos, Miletos, Paros (Marathi, Marathi lychnites, Chorodaki [Pa/ Cho]), Pentelicon [Pe], Proconnesos [Pro], and Thasos calcitic. ${ }^{16}$ Each ellipse incorporates the isotopic analysis results for multiple samples collected by Dr. Attanasio from that quarry. Altogether, his database contains 852 samples from the quarries listed. ${ }^{17}$

Dr. Attanasio calls the rounded fields for the quarries their probability ellipses. As he explains in his report, the closer to the centre of an ellipse a sample of unknown provenance is positioned, the more likely it is to come from the quarry represented by that ellipse (see Table 2 in Appendix 1 for the relative and absolute probabilities that the 27 samples have been correctly assigned to quarries). If there were no overlap of the ellipses for the quarries, secure assignments to quarries of samples of unknown provenances could be made on the basis of stable isotope analyses alone. However, as is immediately apparent from the two graphs, there is extensive overlap of the quarries' probability fields. For example, the field for Carrara lies completely inside the field for Proconnesos. Thus, neither quarry can be eliminated as a possible provenance for samples whose isotopic results fall inside both fields.

If the same samples that fall within both quarry fields are analysed in additional ways, discrimination between Carrara and Proconnesian marble can be achieved. For example, the manganese $\left(\mathrm{Mn}^{2+}\right)$ concentration or intensity of Proconnesian marble, as determined by EPR analyses, is much lower than that of Carrara marble (see the data for quarries at the end of Table 1). This difference in intensity results in an almost complete separation of the EPR fields for Carrara and Proconnesos that are plotted in Graph 4. Note that here all the samples in the Carrara field (see samples 11 and 12 from Figure 5.2) are located outside of the field for Proconnesos (see samples 26 and 27 from Figure 5.3). However, in Graph 4 there is still overlap between the fields for Pentelicon and

16 The quarries for which abbreviations are provided are those whose ellipses are included in Graphs 2-3. The quarries for which abbreviations are not provided were considered as possible provenances, but their ellipses are not shown in Graphs 2-3. For information on the periods of use of these quarries, see Attanasio 2003; and Attanasio et al. 2006.

17 Attanasio et al. 2006, 65, Table 2.2. 
Afyon, which resulted in uncertainty of quarry assignment regarding samples 4-5 (Figure 5.4), and samples 13 and 14 (from the chest of Figure 5.1).

To continue the description of the analyses of the 27 samples, after Ms. Cox finished conducting the stable isotope analyses, she sent the delta numbers of the results to Dr. Attanasio. Using statistical commercial software (STATISTICA 7.1 and SPSS 13.0), he then gave different weights to the six experimental variables or discriminants that he now had for the 27 samples - the delta numbers for the Oxygen 18 and Carbon 13 isotopes, the MGS and colour of the samples, and the intensity and linewidth obtained from the EPR analyses. The purpose of the different weighting was to maximize the separation of the ellipses representing the quarry fields.

Three different formulas were used to determine three different discriminant coordinates for each sample. Discriminant coordinate 1 was the sum of the sample's intensity multiplied by 0.82 , plus the delta number for Oxygen 18 multiplied by 0.64 , plus minor contributions from other discriminants. Discriminant coordinate 2 was the maximum grain size multiplied by 0.88 , plus the intensity multiplied by 0.53 , plus minor contributions from other discriminants. Discriminant coordinate 3 was the delta number for Carbon 13 multiplied by 0.71 , plus the delta number for Oxygen 18 multiplied by 0.63 , plus much less contributions from other discriminants.

These three discriminant coordinates then became the vertical and horizontal axes for Graphs 5 and 6 in Dr. Attanasio's report, which plot the 27 samples and the most important quarry fields. As is evident from Graph 6, sample 14 now falls within the ellipse for Pentelicon and outside that of Afyon. Thus, the marble of the chest of MNR 128581 (Figure 5.1), from which samples 13 and 14 were taken, can be identified as Pentelic. However, sample 4 still falls within the ellipses for both Pentelicon and Afyon on Graphs 5 and 6, and sample 5 falls only within the ellipse for Afyon in Graphs 5 and 6. The micaceous inclusions in the Medea sarcophagus (Figure 5.4), from which both samples 4 and 5 were taken, demonstrates, though, that the marble for both samples must be Pentelic.

\section{Summary of Analysis Results}

Graph 1 in Dr. Attanasio's report summarises the final assignments to quarries that were made on the basis of the isotopic and EPR analyses, and the statistical analyses of the six experimental variables or discriminants. The chests of twenty sarcophagi from the Museo Nazionale Romano were analysed. Five of these sarcophagi had lids, which were also analysed. Thus, a total of 25 pieces were analysed. Fourteen of these pieces proved to be of Proconnesian marble. Twelve 


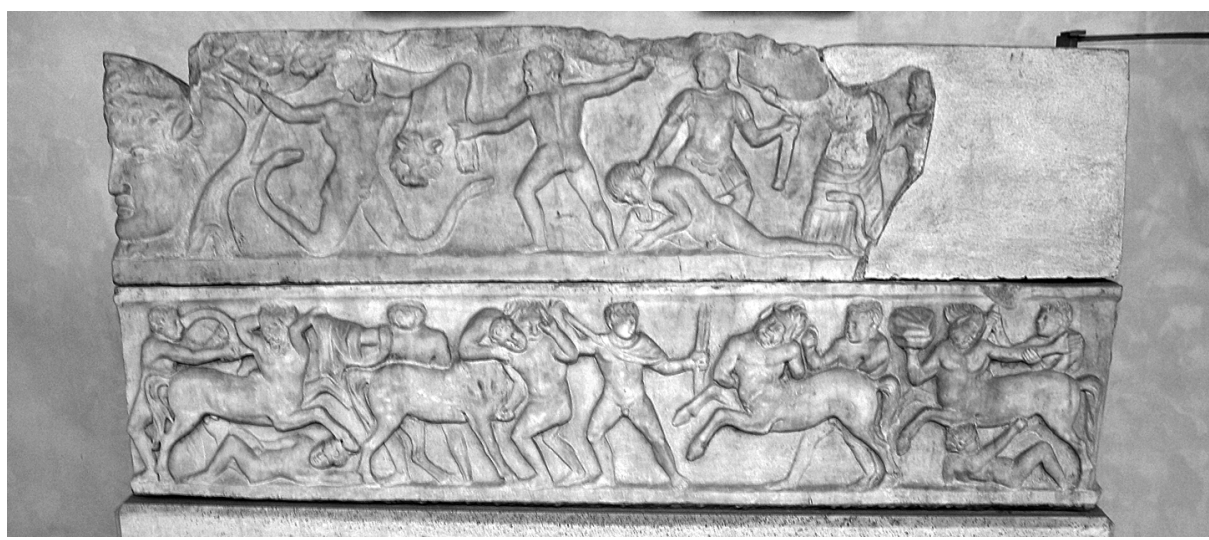

Figure 5.1: Roman child's sarcophagus from Pomezia, c. 140, with Gigantomachy on the lid and Centauromachy on the chest. Lid of Carrara marble and chest of Pentelic marble. MNR 128581 (samples 13-15). Photograph : Frances Van Keuren.

of these pieces are chests from sarcophagi whose lids have been lost. ${ }^{18}$ The thirteenth and fourteenth pieces are a lid and chest from the same sarcophagus (samples 26 and 27 from Figure 5.3). Seven pieces were assigned to Carrara. All but one of these pieces consisted of chests and lids from three sarcophagi (e.g., samples 11 and 12 from Figure 5.2, and samples 21 and 22 from Figures $5.5-5.6)$. The seventh piece is the lid from a sarcophagus whose chest proved to be of Pentelic marble (sample 15 from Figure 5.1). Finally, four pieces were assigned to Pentelicon. Three of these pieces are chests for which the lids have been lost (e.g., samples 4 and 5 from Figure 5.4), and the fourth piece is the chest from the already-mentioned sarcophagus whose lid was identified as Carrara marble (samples 13 and 14 from Figure 5.1).

\section{Sarcophagi Analysed}

\section{Carrara Marble}

The seven samples that have been assigned to Carrara come from the lids and chests of three sarcophagi and the lid of a fourth sarcophagus (Figure 5.1). The earliest of the Carrara pieces is the lid from a child's sarcophagus, found in Pomezia in Latium, of c. 140 (Figure 5.1). The lid depicts a Gigantomachy and

18 In the case of MNR 124735, the sarcophagus was furnished with a flat slab of marble rather than a proper lid. 


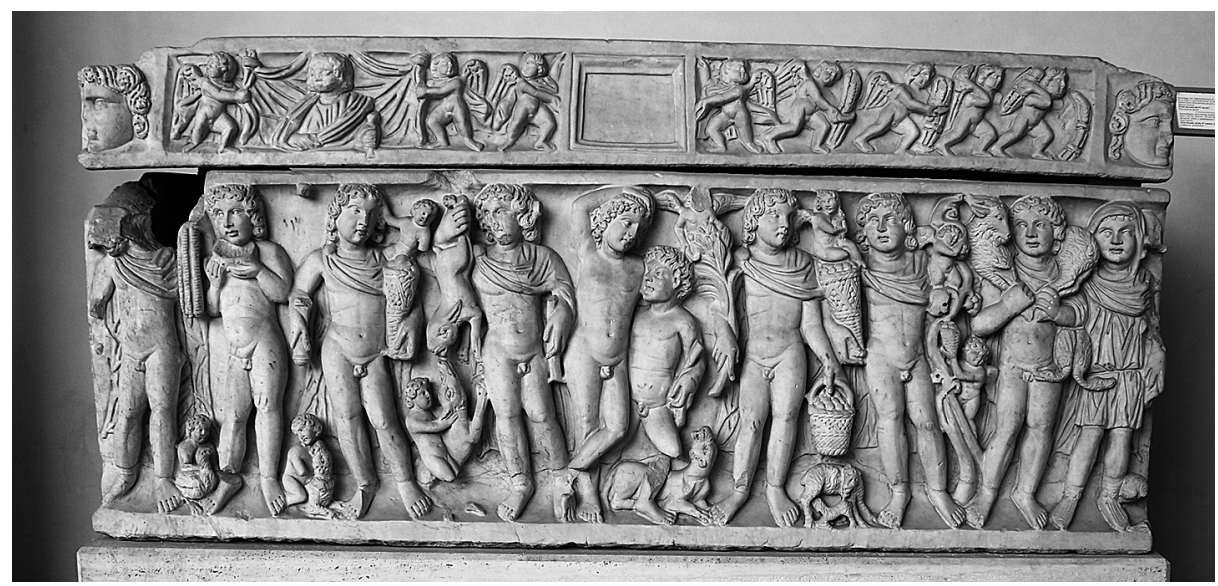

Figure 5.2: Roman sarcophagus of unknown provenance, c. 320, with Dionysos and four Seasons. Lid and chest of Carrara marble. MNR 407 (samples 11-12). Photograph: Frances Van Keuren.

the chest, assigned to Pentelicon, shows a Centauromachy. ${ }^{19}$ The lid and chest of the next Carrara sarcophagus, a garland sarcophagus found in Vigna Casali, Rome, are dated c. 130-150. The chest has a pair of tragic masks above the left garland and a pair of comic masks above the right garland. On the lid are four reclining Seasons. ${ }^{20}$

There is a chronological gap between these sarcophagi from the early Antonine period and the next two sarcophagi from the first half of the fourth century. One, dated c. 320, shows Dionysus and a satyr in the centre of the chest, flanked by the four Seasons. The lid shows the female deceased, a blank funerary tablet, and eight Erotes, four of whom gather grain (Figure 5.2). ${ }^{21}$ This sarcophagus, like the second sarcophagus from the fourth century, appears of be made of reused material, since its lower left corner was added in a separate piece. The chest of the second sarcophagus (Figures. 5.5-5.6), found in a burial chamber on the Via Decima in the Malpasso locality, Rome, and of coarser execution than Figure 5.2, has two strigillated panels that flank a bust of the deceased, a youth wearing a tunic and pallium and holding a scroll, enclosed in a

19 MNR 128581: samples 13, 14 and 15. Sapelli, in Giuliano 1981, 57-58; Koch and Sichtermann 1982, 147; Vian and Moore 1988, 243, no. 501, pl. 154; ASR XII,2, 170 171, no. 148, pls. 120-121; and Huskinson 1996, 27, no. 2.5 .

20 MNR 121657: samples 2-3. Honroth 1971, 57-58, and 89, no. 107; Dayan and Musso, in Giuliano 1981, 144-146; ASR VI,2,1, 118, no. 61.

21 MNR 407: samples 11-12. Musso, in Giuliano 1981, 128-131; ASR IV, 4, 448, no. 256. 


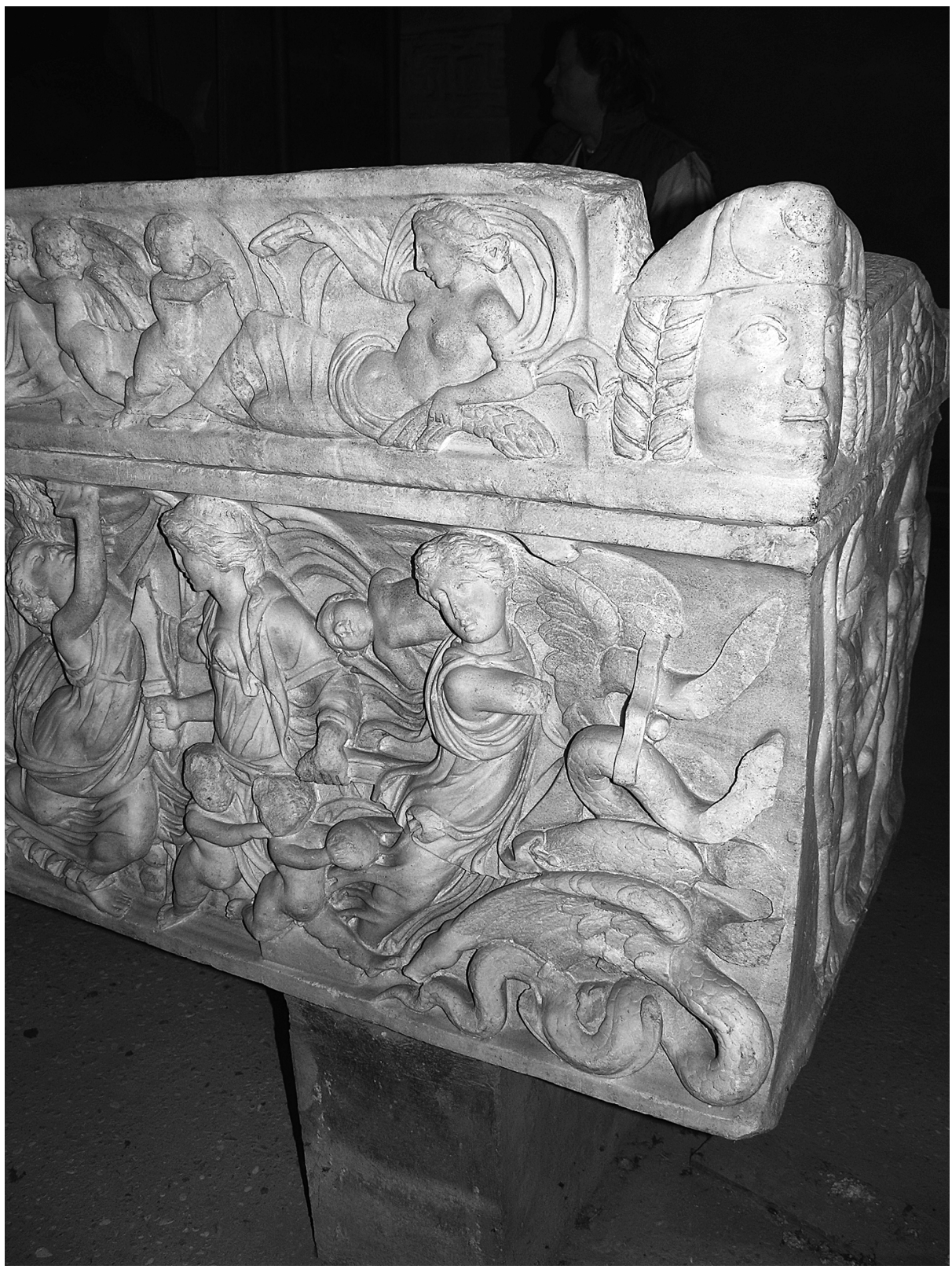

Figure 5.3: Detail of right front of Roman sarcophagus from Via di Porta Maggiore, Rome, c. 150-160, with story of Creusa and Medea. Lid and chest of Proconnesian marble. MNR 75248 (samples 26-27). Photograph: Frances Van Keuren. 


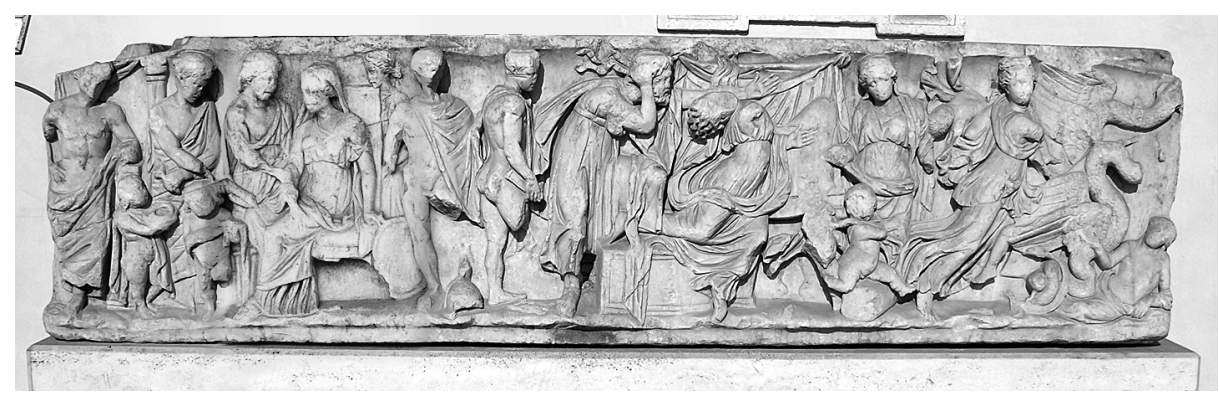

Figure 5.4: Roman sarcophagus dated c. 170, and known since the late sixteenth century, with the story of Creusa and Medea. Pentelic marble. MNR 222 (samples 4-5). Photograph: Frances Van Keuren.

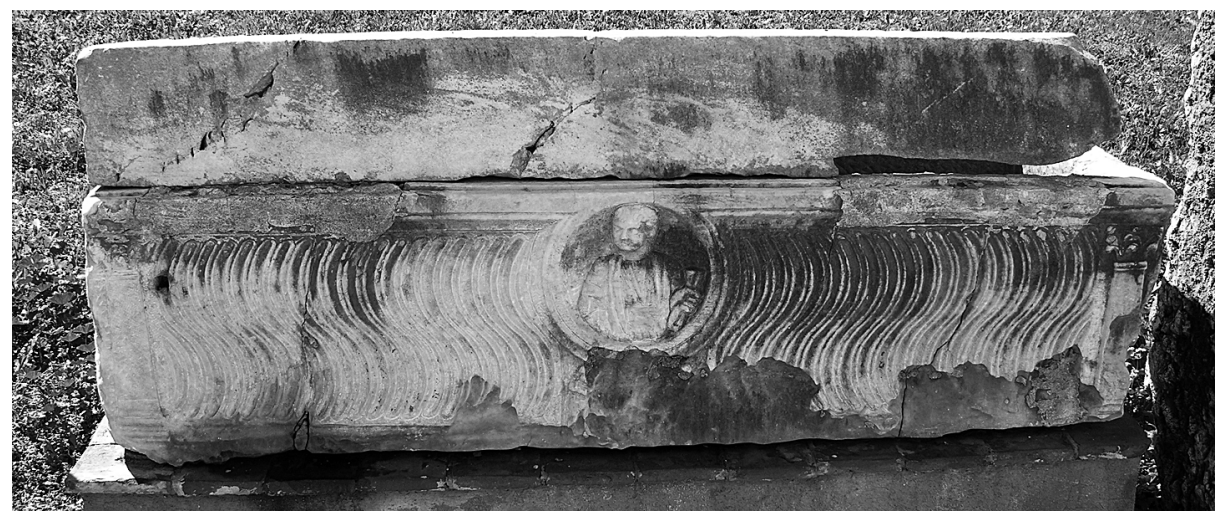

Figure 5.5: Roman sarcophagus from a burial chamber on the Via Decima, Rome, c. $300-$ 350, with two strigillated panels that flank a bust of the deceased youth. Lid and chest of Carrara marble. MNR 115247 (samples 21-22). Photograph: Frances Van Keuren.

roundel, which evokes a shield (clipeus). ${ }^{22}$ The undecorated lid is too deep for its chest and sawn, not chiselled. The chest of this sarcophagus, which appears to have been executed in the first half of the fourth century, may be a reworked block. The diagonal division and the stray holes on its back side strongly suggest reuse. $^{23}$

22 MNR 115247: samples 21-22. Pietrogrande 1934, 166-168; Dayan, in Giuliano 1982, 79-80.

23 Email from John J. Herrmann, Jr. of October 31, 2008. For further discussion of these sarcophagi, see Herrmann, Appendix 2 below. 


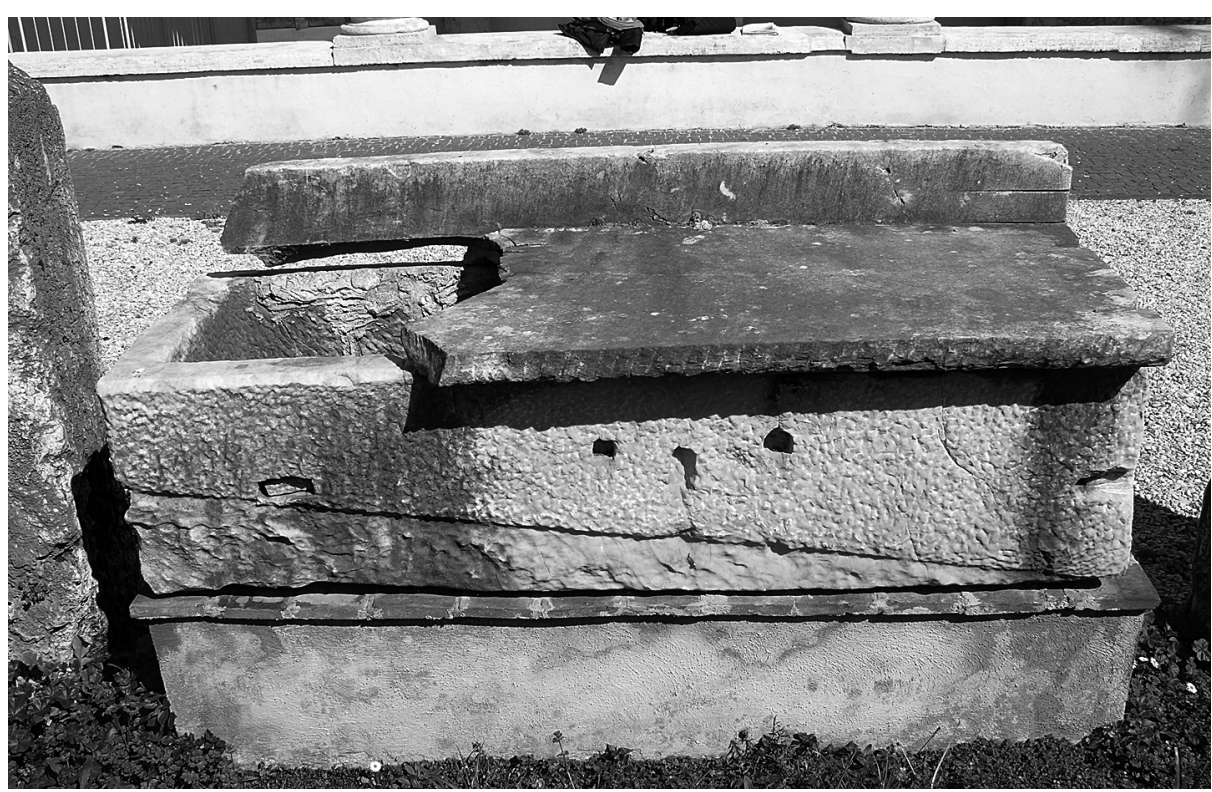

Figure 5.6: Back side of Figure 5.5 showing evidence of a previous use. Photograph: Frances Van Keuren.

\section{Proconnesian Marble}

Thirteen sarcophagi at the Museo Nazionale Romano proved to be made of Proconnesian marble. The sarcophagi range in date from the middle Antonine period, through the third century.

The first piece, a child's sarcophagus of c. 150, depicts Meleager and the Calydonian boar in the central columned niche, flanked on each side by a strigillated panel; on the far left, Atalanta stands with a hound, and on the far right is a second hero. ${ }^{24}$

The second sarcophagus was found in a funerary chamber on the Via di Porta Maggiore, Rome. The detail of the right front in Figure 5.3 clearly shows the grey banding that is characteristic of Proconnesian marble. ${ }^{25}$ Dated c. $150-$ 160, the sarcophagus illustrates the story of Creusa and Medea on the front of

24 MNR 56138: sample 8. ASR XII,6, 130-131, no. 144, pls. 120 and 122; Musso, in Giuliano 1981, 115-117; Woodford 1992, 422-423, no. 71, pl. 215; and Huskinson 1996, 28, no. 2.20.

25 Attanasio et al. 2006, 201; and Attanasio et al. 2008, 748. 
the chest. ${ }^{26}$ On the left, Creusa receives the fatal wedding gifts from Medea's children. In the centre, she is consumed by the flames from the poisoned robe, in the presence of her father, King Creon of Corinth. On the right, Medea contemplates killing her two sons by Jason, and then flies away with their bodies on her chariot drawn by two winged serpents. The lid shows four reclining Seasons.

The third middle Antonine sarcophagus, of unknown provenance, has an inscribed tablet on the centre of the chest with the name of Lucius Tuccius Corinthianus. On each side the tablet is upheld by a Nike flying above an overturned basket containing fruit on one side and flowers on the other. ${ }^{27}$

The next Proconnesian sarcophagus, dated to the late Antonine period, is of special interest because of its extensive paint traces. Found on the Via Lidia, Rome, it has an oak wreath in the centre of the chest enclosing the name of Ulpia Domina. A pair of Nikai supports the wreath, and beneath each one is a cornucopia. A winged genius with downturned torch stands on the far left and far right. $^{28}$

A fragment of a sarcophagus from the late second century shows a draped reclining male, who leans on an animal that is probably a dog. Identified as Endymion, this figure was probably from the right corner of the front of a chest, as on a sarcophagus with the same theme in the Louvre. ${ }^{29}$

On a child's sarcophagus of c. 200 two Erotes hold up a shield inscribed with the name of Publius Flavius Alexander at the centre of the chest. Two Erotes on the left drag a goat to sacrifice, while two more Erotes on the right stand at an altar. ${ }^{30}$

Another sarcophagus dated c. 200 was for the burial of a girl. She is depicted in the centre of the chest inside a laurel wreath, which is supported by a pair of flying Erotes. On the far left and far right are Cupid and Psyche embracing. ${ }^{31}$

26 MNR 75248: samples 26-27. Schmidt 1968, 21, 45 note 4, pl. 32.2; Musso, in Giuliano 1985, 279-283; Berger-Doer 1992, 122, no. 5, 124, no. 21, pl. 54; and Gaggadis-Robin 1994, 12, no. 8, figs. 10-12.

27 MNR 72879: sample 9. Dayan, Musso and Friggeri, in Giuliano 1981, 104-105.

28 MNR 125891: sample 6. Dayan, Musso and Friggeri, in Giuliano 1981, 86-88.

29 MNR fragment without inventory number: sample 20. Sapelli, in Giuliano 1982, $72-$ 73; and ASR XII,2, 159, no. 116, pl. 113.4. The Louvre sarcophagus, dated to the early third century, is in Baratte and Metzger 1985, 67-69, no. 23; and ASR XII,2, 117-118, no. 55, pl. 51.1. University of Georgia graduate student Maria Graffagnino found the iconographic parallel of the Louvre sarcophagus.

30 MNR 226119: sample 16. Dayan, Musso and Sabbatini Tumolesi, in Giuliano 1981, 48-49; and Huskinson 1996, 50, no. 6.32.

31 MNR sarcophagus without inventory number: sample 25. Musso, in Giuliano 1981, 98-99; Blanc and Gury 1986, 981, no. 202, pl. 692; Huskinson 1996, 53, no. 7.6, where the marble is identified as Carrara. 
A sarcophagus dated c. 220 and found on the Via Casilina in Rome, shows a portrait bust of the deceased in a clipeus, which is held by two flying Genii. Beneath the clipeus are an eagle, Oceanus and Tellus, and on the far left and far right edges of the chest are groups of Cheiron instructing Achilles in the lyre. ${ }^{32}$

A very well preserved, round-ended chest, resembling a vat (lenos), was found in Tomb D on the Via Belluzzo, Rome. Although it has the size of an adult sarcophagus, the lenos contained the skeleton of a ten-year-old girl. It is decorated with strigillations and two clipei with busts of Helios and Selene, which both appear to have the face of the deceased. ${ }^{33}$ In the excavation report, Rita Santolini dates the lenos to the first decades of the third century, but stylistically it resembles the 'Badminton Sarcophagus' in New York, a lenos that is itself difficult to date but which must be from the late Severan period or later. $^{34}$

A fragmentary lenos featuring the musical contest between the satyr Marsyas and Apollo, and the subsequent flaying of Marsyas, is another sarcophagus that exhibits stylistic similarities to the 'Badminton Sarcophagus'. The part of the lenos that is preserved is the base and the lower part of the sculptured figures. It was found with parts of many other sarcophagi, in a dump close to the Trastevere station, Rome. Additional fragments that show the upper parts of figures from the musical contest and flaying, and that match the missing parts of the two scenes on the lenos, clearly come from its front and right sides. These matching fragments are located at the National Gallery in Oslo and the Metropolitan Museum of Art in New York. ${ }^{35}$ All three portions have now been analysed, with results that exhibited unexpected variations. ${ }^{36}$ These variations

32 MNR 124735: sample 10. Sapelli, in Giuliano 1981, 90-93; ASR XII,1, 195, no. 3.

33 Sample 1. Santolini 1986-87, 130-134; Gury 1994, 707, no. 1. University of Georgia graduate student Soon Bae Kim identified the closest iconographic parallel for the lenos, a funerary altar of Iulia Victorina from the late first century, which shows the deceased child both in the guise of Luna and Sol. See Letta 1988, 623, no. 454, pl. 384.

34 For the Badminton Sarcophagus, see note 70 below. In an email of December 7, 2008, John J. Herrmann Jr. noted these common features in the two lenoi: 'Smooth and rubbery [treatment]. Flowing hair curling around a drill hole. Identical hands around shaft of pole or thyrsus. Similar facial proportions - and simplified modelling ... Generally simplified, easy stylisation.'

35 MNR lenos without inventory number: sample 23. Bartoli 1953, 1-2, fig. 1; McCann 1978, 79-84, no. 13; Sande 1981; Musso, in Giuliano 1982, 82-86, where the marble is identified as Carrara; Rawson 1987, 184-186, no. XX, figs. 5, 18 and 57. Mancini 1913, 117-118, who reported on the initial discovery of the lenos, wrote: 'Fra la terra di scarico si rinvennero in grande quantità resti di sarcofagi.'

36 The results of these additional analyses were presented in a poster at the IX International Conference ASMOSIA (Association for the Study of Marble and Other Stones in Antiquity): Interdisciplinary Studies on Ancient Stone, Tarragona, 8-13 June 2009. Entitled 'Isotopic, EPR and Petrographic Analyses of 20 Roman Sarcophagi at the Museo Nazionale Romano, Rome', the poster was co-authored by Frances Van Keuren, 
may be due to the quarrying of the block for the lenos from the C-5 part of the Proconnesian quarries, where samples of large variability were collected. ${ }^{37}$

A sarcophagus with a funerary tablet bearing the name Aurelia Luciosa was found on the Via del Corso in Rome. The tabula ansata is flanked by two strigillated panels, and on the far left and right corners of the chest are Composite pilasters. The sarcophagus may have been produced in the third century. ${ }^{38}$

A sarcophagus from the Via Fezzan in Rome is difficult to date. According to Anna Maria Ramieri, the treatment of the two strigillated panels that flank the inscription tablet indicates that that the piece is one of the earliest examples of strigillated sarcophagi from the second century. Marina Bertinetti concludes that the inscription with the names of Lollia Valeria Maior and her husband Gaius Sicinius Olympius is later than the sarcophagus, i.e. from the third or fourth century. The latter scholar suggests, though, that the inscription may indicate a reuse of the sarcophagus in late antiquity. ${ }^{39}$

A fragment from the left corner of the front of a sarcophagus has not been dated, evidently due to the poor state of preservation of its surface. It depicts a nude male who moves to the right, while standing on tiptoe with his right leg advanced. He twists his torso back to the viewer's left, while raising a syrinx in his right hand. Over his left shoulder is an animal skin, and a panther bounds to the right at his feet. This figure was identified as Pan by Friedrich Matz, an identification which was followed by Anna Maria Ramieri. ${ }^{40}$ However, the absence of goat legs on this figure and the uncertain nature of the flame-shaped protuberance over his forehead raise questions about his identity. Since he closely resembles a tiptoeing satyr with a syrinx on a lenos in Dresden, he seems more likely to be a satyr with a flame-shaped hair strand or ornament on a fillet. ${ }^{41}$

Julia Cox, Shelby Hipol, Donato Attanasio, John J. Herrmann, Jr., and Dorothy H. Abramitis. These analyses should also be published, in article form, in the conference volume.

37 Attanasio et al. 2008, 762-764; and email from Donato Attanasio of September 24, 2009.

38 MNR 524: sample 19. CIL 6.2, 1610, no. 13343; Ramieri and Bertinetti, in Giuliano $1982,64-65$.

39 MNR 126285: sample 18. Ramieri and Bertinetti, in Giuliano 1982, 62-64. The initial discovery of the sarcophagus is reported by Felletti Maj 1953, 234-235, fig. 1.

40 MNR 750: sample 17. ASR IV, 4, 482, no. 317; Ramieri, in Giuliano 1982, 107-108.

41 For the sarcophagus in Dresden, see $A S R$ IV, 1, 159-161, no. 52, pl. 60. The satyr with the syrinx is Matz's figure type TH 61 (vol. 4, pt. 1, 44). Maria Graffagnino found this useful iconographic parallel. 
Pentelic Marble

Three sarcophagi and the chest of a fourth were revealed to be of Pentelic marble. The earliest of the Pentelic pieces, a child's sarcophagus of c. 140, has already been discussed above, since the lid is of Carrara marble (see Figure 5.1). The chest, which shows a Centauromachy, is of Pentelic marble. ${ }^{42}$ In spite of the difference of material, the lid and chest appear to have been carved by the same workshop.

A sarcophagus fragment, found at Ostia and dated c. 150-160, comes from the right corner of the front of a chest. The fragment is from a depiction of Pluto's rape of Proserpina. The horses from Pluto's chariot and the figure of Mercury who leads them to the Underworld are preserved, along with the thrown-back head, right arm and left foot of Proserpina, and the left thigh and knee of Pluto on his chariot. ${ }^{43}$ There is also a second fragment believed to come from the same sarcophagus that shows the chariot with winged serpents belonging to Ceres. Although this fragment is reported to be in the Magazzini of the Museo Nazionale Romano, it could not be found for testing. ${ }^{44}$

Slightly later in date than the Proconnesian sarcophagus with the story of Creusa and Medea (Figure 5.3) is a Pentelic sarcophagus with the same theme (Figure 5.4). ${ }^{45}$ On this second Medea sarcophagus, dated c. 170, the groupings of characters are arranged in a fashion very similar to the earlier example. Unfortunately, the surface of the Pentelic sarcophagus is very worn, evidently because it has been known since the sixteenth century, which makes stylistic comparison with the Proconnesian sarcophagus difficult. Nonetheless, the Pentelic sarcophagus appears to exhibit a flatter handling in the modelling of the figures and the drapery treatment, and it seems to rely on deeper drilling of details such as the pupils of the eyes. Thus, the two sarcophagi may well be the products of two different workshops, but they were clearly using common figural compositions, perhaps transmitted by means of copybooks with line drawings.

42 MNR 128581: samples 13, 14 and 15. Sapelli, in Giuliano 1981, 57-58; Sengelin 1997, 712, no. 404b, pl. 463; and Huskinson 1996, 27, no. 2.5.

43 MNR 654: sample 24. Visconti 1866, 325, pl. S.2 (engraving); ASR III, 3, 459-460, no. 360; Musso, in Giuliano 1982, 109-111.

44 Sichtermann 1974, 313-314, fig. 7; Blome 1978, 456. University of Georgia graduate student Katie Seefeldt researched this sarcophagus fragment and its iconographic parallels, which are listed in Angeli 1988, 901, nos. 126-134.

45 MNR 222: samples 4-5. Musso, in Giuliano 1981, 138-143; Berger-Doer 1992, 122, no. 7, pl. 53; Schmidt 1992, 393, no. 53, pl. 200; Gaggadis-Robin 1994, 17-18, no. 21, figs. 32-34. University of Georgia graduate student Chad Alligood researched the two Medea sarcophagi (Figures 5.3-5.4), and studied their iconographic similarities. 
The latest Pentelic piece is a child's sarcophagus from Ostia, dated c. $280-$ 300. In the centre of the chest is a portrait of an adult male in a clipeus, which was reworked from a portrait of a boy with a Horus lock. The clipeus is held up by a pair of standing Erotes, and beneath it is a cock fight. Two more Erotes with ducks and a rabbit stand on the far left and far right edges of the chest. ${ }^{46}$

\section{Dolomitic Marble from Cape Vathy, Thasos}

The genesis for undertaking the marble analyses reported in this article was the work on the sarcophagi at the Museo Nazionale Romano by John J. Herrmann, Jr., and Richard Newman. Using the definitive techniques of X-ray diffraction and the electron-beam microprobe, they determined that seven of the sarcophagi in the Chiostro Grande were made of dolomitic marble from the quarries on Cape Vathy, Thasos. ${ }^{47}$ Dolomitic marble is composed almost entirely of the mineral dolomite, i.e. calcium-magnesium carbonate. ${ }^{48}$ The attribution to Thasos was reinforced by the macroscopic characteristics of the marble (coarse grain and virtually unmarked white colour). The goal of the project whose results are presented in this article was to determine what calcitic marbles were attested in some of the additional sarcophagi in the Chiostro Grande, besides those of dolomitic marble.

Robert H. Tykot provides this explanation of X-ray diffraction and the electron-beam microprobe:

These methods involve the measurement of characteristic wavelengths of electromagnetic radiation ... absorbed or emitted when a sample is 'excited' (e.g. by bombardment with ... X-rays, or electrons). A complex spectrum is produced in which peaks at certain wavelengths are characteristic of one or more elements, and the area under a peak (intensity) is proportional to the amount of that element present in the analyzed material. ${ }^{49}$

46 MNR 128086: sample 7. Schauenburg 1972, 512, note 53; Musso, in Giuliano 1981, $100-102$; ASR V, 4, 197, no. 46; Blanc and Gury 1986, 982, no. 214; Huskinson 1996, 65, no. 9.29.

47 The analyses were conducted at the laboratory of the Museum of Fine Arts in Boston. See Herrmann and Newman 1995, 82; Herrmann and Newman 1999, 301; and Herrmann 1999, 57-58, 63, and 69. Another definitive technique for distinguishing calcitic from dolomitic marble is the application of dilute hydrochloric acid to a marble surface, chip or flakes. When there is no effervescence or fizzing, to use the layman's term, the marble must be dolomitic. When, on the other hand, there is effervescence, the marble must be calcitic.

48 Herz 1988, 236-237.

49 Tykot 2004, 410. 
The seven sarcophagi from the Museo Nazionale Romano of dolomitic marble from Cape Vathy range in date from the Trajanic through the early Severan period. ${ }^{50}$ The earliest one, found in Ostia and dated to the Trajanic period, belongs to a Greek artisan from Ephesus named Titus Flavius Trophimas. To the left of the inscription tablet, located on the centre of the chest, are depictions of Trophimas' two friends, who are shown practicing their crafts of shoemaking and rope making. Trophimas himself is shown to the right of the inscription tablet, in the role of an Isiac initiate. ${ }^{51}$

The second sarcophagus, found on the Via Aurelia in Rome and dated c. $120-150$, contained the body of a ten-year-old girl named Flavia Sextiliane. The centre of the chest has the girl's name inscribed on a clipeus that is borne by a pair of flying Erotes. Additional Erotes stand with torches on the left and right edges of the chest, and the lid is decorated with more Erotes, some with arms. ${ }^{52}$

Two later sarcophagi of Antonine date depict Erotes making arms. One of the sarcophagi is from the Ponte Rotto in Rome, and the other has an unknown provenance. These sarcophagi share the motif of a shield in the centre of the chest, which is supported on the right by an Eros who stands with his head turned back and away from the shield. ${ }^{53}$ The same motif can be found on a fragment of the Trajanic frieze from the temple of Venus Genetrix in Rome, which is believed to have served as a source of inspiration for all three sarcophagi from the Chiostro Grande that show Erotes with arms. ${ }^{54}$

Three Dionysiac dolomitic sarcophagi show a satyr and two maenads from Friedrich Matz's repertoire of Neo-Attic figure types. The survival of these Dionysiac types until the late Antonine and early Severan periods, when these sarcophagi are believed to have been produced, demonstrates the longevity of such figure types. Outline renderings of favourite Dionysiac figure types, kept in sarcophagus workshops, would be one possible means to preserve knowledge of such figure types over the centuries.

The first two Dionysiac sarcophagi appear to be contemporary, since they both have been dated c. 170-180. Each one was found in Rome and shows Dionysus in a chariot drawn by centaurs. One sarcophagus, found in the church of Sts. Nereus and Achilleus on the Via Appia, depicts the wine god discovering a sleeping Ariadne. The satyr directly to the viewer's right of Ariadne, who holds

50 For a fuller discussion of these sarcophagi, see Van Keuren and Gromet 2009, 198-203.

51 MNR 184: Dayan, Musso and Lombardi, in Giuliano 1981, 148-150. This sarcophagus could not be located in the Chiostro Grande in March, 2008.

52 MNR 128578: Dayan, Musso and Friggeri, in Giuliani 1981, 184-186; Huskinson 1996, 64 no. 9.23.

53 MNR 175 and 900: Dayan and Musso, in Giuliano 1981, 59-61 and 159-160; Blanc and Gury 1986, 1018 no. 541, pl. 715; Huskinson 1996, 42 and 49 nos. 6.27 and 6.29.

54 Floriani Squarciapino 1950, 109 ff.; Hesberg 1981, 1074-1075, fig. 13 (frieze fragment from the temple of Venus Genetrix). 
a lagobolon in his left arm as he lunges to the right, is Matz's figure type TH 18. ${ }^{55}$ The second Dionysiac sarcophagus, found on the Via Aurelia Antica, shows a rapidly-moving flute player in front of Dionysus' chariot. This maenad, who raises her arms high to play her instrument, belongs to Matz's type $\mathrm{TH}$ $36 .{ }^{56}$

On the last Dionysiac sarcophagus from the early Severan period, the wine god again rides in a chariot drawn by two centaurs. To the right of his chariot is an ecstatic maenad with billowing drapery who raises her tympanum high while throwing her head back. She is an example of Matz's Neo-Attic type TH 27. ${ }^{57}$ Although this maenad strikes the tympanum rather than playing the double flute, she is very close in pose to the maenad of type TH 36 on the previous Dionysiac sarcophagus, which suggests that standard figure types could be altered to play slightly different roles.

\section{Conclusion}

The earliest sarcophagus from those at the Museo Nazionale Romano that have been analysed is from the Trajanic period, and is made of dolomitic marble from Thasos. Found in Ostia, the sarcophagus was made for a Greek artisan from Ephesus named Trophimas. This evidence suggests that immigrants like Trophimas may have introduced burial in marble sarcophagi in Rome's port city, a practice which then spread to the broader populace of Rome.

Pentelic marble was used in Rome for Imperial monuments of special significance in terms of their propagandistic content - for example, the Arch of Titus, and the Trajanic Frieze that was reused on the Arch of Constantine. ${ }^{58}$ The emphasis on mythological content on all but one of the Pentelic sarcophagi suggests the erudition and hence the high social status of the families who purchased them. The earliest of the sarcophagi, dated c. 140, is a chest from a child's sarcophagus that is decorated with a Centauromachy (Figure 5.1). Two sarcophagi for adults, dated to the third quarter of the second century, feature Pluto's abduction of Proserpina and the tragic stories of Creusa and Medea (Figure 5.4). Only the latest Pentelic sarcophagus from the end of the third century, which has a re-cut head of the deceased, lacks a mythological storyline.

55 MNR 214: ASR IV, 3, 399-400, no. 225; Musso, in Giuliano 1981, 123-125; Gasparri 1986, 555, no. 191. For figure type TH 18, see ASR IV, 1, 25, no. TH 18.

56 MNR 128577: ASR IV, 2, 251-252, no. 108; Musso, in Giuliano 1981, 64-66. For figure type TH 36, see $A S R$ IV, 1, 33, no. TH 36.

57 MNR without inventory no.: ASR IV, 2, 257-258, no. 117; Musso, in Giuliano 1981, 119-121. For figure type TH 27, see ASR IV, 1, 30, no. TH 27.

58 Amadori et al. 1998, 48-49. 
Perhaps the most interesting discovery regarding the 20 sarcophagi at the Museo Nazionale Romano that were analysed for this study is the discontinuity in the use of Carrara marble. The lid of the just-mentioned child's sarcophagus (Figure 5.1) and the lid and chest of another sarcophagus, both dated to the early Antonine period (c. 130-150), were revealed to be of Carrara marble. No sarcophagus from the second half of the second century or the third century is made of this marble. The absence of Carrara sarcophagi from the late second century coincides with a marked decrease in the use of Carrara marble in the public buildings of second-century Rome. ${ }^{59}$ The lack of third-century Carrara sarcophagi is consistent with Susan Walker's conclusion regarding the 'sharp decline in the use of Carrara marble for sarcophagi decorated at Rome in the third century AD. ${ }^{60}$ Note too that Carrara is not included in the list of quarries in Diocletian's Edict on Maximum Prices of $301 .{ }^{61}$ However, two sarcophagi dated to the first half of the fourth century (see Figures 5.2 and 5.5-5.6) indicate that there was a revival in the use of Carrara marble in late antiquity. Multiple analysis methods have revealed that Carrara marble was also used in the Constantinian friezes and clipei from the Arch of Constantine. ${ }^{62}$

A renewed interest in Carrara marble during the fourth century is consistent with Walker's suggestion of 1988 that 'there is reason to suppose a limited revival of the use of Carrara in Constantinian Rome. It is not yet clear whether the revival concerned freshly quarried, stockpiled or reused blocks. ${ }^{63}$ In Appendix 2 at the end of this article, John J. Herrmann, Jr. suggests that both of the Carrara sarcophagi from the fourth century that were analysed (Figures 5.2 and 5.5-5.6) were made from reused materials, along with a large proportion of Early Christian sarcophagi from the Museo Pio Cristiano at the Vatican.

In her article of 1988, Walker accepted the theory that during the fourth century, the port for Carrara was an estuarine lake to the west of Luni, itself located to the southwest of Carrara on the Ligurian Sea. According to this theory, in the fourth century the port would have become overgrown with reeds and Luni itself damaged by flooding. ${ }^{64}$ However, Paolo Fazzini and Marina Maffei proposed in 2000 that the Roman port for Luni may have been located instead in 'a sheltered fluvial inlet along a bend of the R. Magra, near its mouth.' They did not find evidence of extensive destruction of Luni until the second half of the seventh century, when there were three 'catastrophic flooding

59 Bruno et al. 2002, 298.

60 Walker 1988b, 187. See also Walker and Matthews 1988, 124.

61 For the list of quarries in this edict, see Lauffer 1971, 192-193, no. 33; Roueché 1989, $299-300$.

62 Amadori et al. 1998, 49.

63 Walker 1988b, 189-190.

64 Walker 1988b, 190. 
events. ${ }^{65}$ Thus, the reason for the decline in the use of Carrara marble for sarcophagi after 150 may not be the clogging up of the harbour of Luni.

A consideration of price may have led to the apparent preference during the late second and third centuries for the two marbles most strongly represented in our late Antonine and Severan test group. According to Diocletian's Edict of 301, Proconnesian marble was the cheapest and Thasian marble was only slightly more expensive, while marble from Afyon was far more expensive than both island marbles. ${ }^{66}$ Of the 20 sarcophagi from the Museo Nazionale Romano that were analysed for this study, the majority, i.e. twelve chests and the lid and chest of a thirteenth sarcophagus (Figure 5.3), were revealed to be of the cheapest Proconnesian marble. This statistic supports Walker's observation that 'by eye it would appear that Proconnesian ... became the most favoured Greek marble for metropolitan sarcophagi. ${ }^{167}$ Significantly, the earliest of the thirteen Proconnesian sarcophagi was produced c. 150 in the middle Antonine period, just after the second-century sequence of Carrara sarcophagi in the analysed group ended in the early Antonine period. Ten of the thirteen Proconnesian sarcophagi can be dated, on the basis of their figural decoration. Five fall in the second half of the second century. The popularity of Proconnesian marble in sarcophagi from 150-200 coincides chronologically with its first use in Rome for 'major public works. ${ }^{\text {'68 }}$

It may be significant that Parian marble did not appear among our second century sarcophagi. Parian lychnites was certainly used for sculpture in Rome at that time, ${ }^{69}$ but this traditionally high-status marble may well have been largely restricted to high-status projects, such as statuary. It may not, as this group of tests suggests, have only occasionally been used by workshops producing sarcophagi.

The five additional Proconnesian sarcophagi that can be dated were produced in the third century. Three belong to the first two decades of the third century, i.e. the Severan period. Two further Proconnesian sarcophagi may date either from the late Severan period or the time of the Soldier Emperors (235280). Stylistically they compare rather closely to the famous 'Badminton Sarcophagus', which has recently been revealed to be of Parian Lychnites marble through multiple analysis techniques. This sarcophagus has been dated from c.

65 Fazzini and Maffei 2000. See also Bini, Chelli and Pappalardo 2006, for their study on the location of the coastline around Luni during Roman times.

66 Gnoli 1971, 14-16; and Dodge and Ward-Perkins 1972, 177-178.

67 Walker 1988a, 30.

68 Attanasio, Brilli and Bruno 2008, 752.

69 Herrmann et al. 2000, 258 and 260, fig. 11: Hadrianic head of Artemis from Grottaferrata. See also Pensabene et al. 2000: irregular Parian blocks with consular dates of $132,153,163,164$. 
230 to as late as c. 270 . The treatment of its back side shows that it is a reused entablature block. ${ }^{70}$

The period of the Soldier Emperors corresponds to a time of change - and perhaps crisis - in the Roman marble trade, as in Roman civilization generally. Symptomatic in the realm of marble is the disappearance of control marks with consular dates on marble blocks after the first decade of the third century. ${ }^{71}$ Nonetheless, Diocletian's Edict on Maximum Prices, issued in 301, demonstrates that quarrying continued at some locations until the early fourth century, even if only for marble veneer. ${ }^{72}$

Production of sarcophagi continued at Rome through the time of the Soldier Emperors, as is shown by other famous sarcophagi of that time, such as the 'Ludovisi Battle Sarcophagus ${ }^{73}$ and the 'Sarcophagus of the Annona', ${ }^{74}$ both of which have grey bands and appear to be Proconnesian marble. Three types of lenoi that were decorated with heads of lions and full figures of lions were produced during the third century. Susan Walker suggests that production of the third type, with full figures of lions that bring down prey, continued until the end of the third century. Isotopic analyses revealed that Proconnesian marble was used for the majority of the first two types, but for less than half of the third type. ${ }^{75}$ Two additional lenoi of the third type have been tested, and one proved to be Proconnesian, ${ }^{76}$ while the other was Pentelic. ${ }^{77}$ The shipwreck off San Pietro on the Italian coast near Taranto, dated by its late Roman pottery to the first half of the third century, carried nine roughed-out examples of Walker's first type of lenos and three roughed-out examples belonging to her second or third type. Isotopic analyses demonstrated that all of them were of dolomitic Thasian marble. ${ }^{78}$

The standard practice for the production of Roman sarcophagi seems to have been to rough out the shape of the sarcophagus in the quarry. ${ }^{79}$ This process involved the roughing out of the basic shape of each sarcophagus, and

70 McCann 1978, 94-106; and Bartman 1993. The recent analyses revealing the sarcophagus is of Parian Lychnites are being presented at the first symposium of the International Association of Roman Sarcophagi, Marburg, 2-8 October 2010.

71 Amadori et al. 1998, 52: 'dopo il primo decennio del III secolo non s'incontrano più nei blocchi grezzi delle cave le consuete numerazioni, sigle e nomi delle officine.'

72 Corcoran and DeLaine 1994.

73 De Angelis d'Ossat 2002, 218-221.

74 Andreae 1977, 304, fig. 597.

75 Walker 1985.

76 A Proconnesian lenos in Toledo of c. 240: Knudsen et al. 2002, 237, fig. 9.

77 A Pentelic lenos in Boston of c. 260-270 (MFAB 1975.359).: http://www.mfa.org/ collections/search_art.asp?coll_keywords $=1975 \% 2 \mathrm{E} 359$

78 Ward-Perkins and Throckmorton 1965; Walker 1985, 62-63; Alessio and Zaccaria 1997; Herrmann 1999, 63.

79 See Wurch-Kozelj and Kozelj 1995. 
the removal of the interior of the chest, evidently in order to lighten the load during shipping. ${ }^{80}$ Sarcophagi were sometimes the only type of marble cargo on Roman ships, as in the case of the San Pietro wreck, which contained dolomitic marble sarcophagi of rectangular shape as well as oval lenoi. ${ }^{81}$ In other cases, as in the Torre Sgarrata wreck, roughed-out sarcophagi as well as un-worked marble blocks were shipped together. ${ }^{82}$ However, in Rome's marble yards, roughed-out sarcophagi are not found with un-worked, evidently discarded blocks. ${ }^{83}$ Ben Russell shared these observations:

Like Clayton [Fant], I know of no blocks at Portus or Rome from which a sarcophagus could have been cut - but partly this might be because if any such blocks ever existed they would have been used up, probably in Late Antiquity. The shipwreck evidence is more conclusive - roughed-out blanks or finished pieces only. $^{84}$

Once roughed-out sarcophagi reached Portus (northwest of Ostia) or Rome, they would have been transported to sculptural workshops, where they would have been given carved decoration. Bonanno Aravantinos proposes that in Ostia, such workshops were located near the cemeteries of Pianabella, Laurentina and the Via Ostiense, all located outside the city walls to the southeast. ${ }^{85}$ The basis for this hypothesis was the discovery near these cemeteries of fragments of sarcophagi whose figural decoration is in various stages of execution, with tool marks still visible. ${ }^{86}$ Alternatively, these fragments might instead be pieces of sarcophagi from tombs; i. e., they might be from sarcophagi that were purchased before they had received the finishing touches, and that

80 In an email of February 18, 2004 (her book will be forthcoming), Nusin Asgari reports these types of finds in the Proconnesian quarries: '(1) Roughed out sarc.-chest with 2 bosses on one long side (for the lion heads) - this type is the same as the Thasian quarrylenoi. (2) Roughed out quarry-lenoi without any bosses [Walker 1985, lenos types 2 and 3]. (3) Roughed out quarry-blocks, large and small, in oval form, the interior of which have not as yet been hollowed out.'

81 Herrmann, 1999, 63. For drawings of the sarcophagi as they were found, see WardPerkins and Throckmorton 1965, 208-209; and Alessio and Zaccaria 1997, 215-216, figs. $2-3$.

82 Throckmorton 1989, with drawing p. 269. Calia et al. 2009 and Gabellone et al. 2009 report that, according to isotopic and mineropetrographic analyses, the sarcophagi and the blocks are of two types of Thasian marble, dolomitic from Cape Vathy and calcitic from Cape Phanari.

83 For the marble yards of Portus and Rome, see Maischberger 1997; and Fant 2001.

84 Email communication of May 21, 2009. See also his article in this volume. It appears that sarcophagi of Dokimeian marble were shipped finished, except for portrait heads of the deceased. See Walker 1988a, 33; and Van Keuren and Gromet 2009, 196.

85 Aravantinos 2008, 149-152.

86 Ibid., 150-154, figs. $1-6$. 
were then pressed into service prematurely. ${ }^{87}$ That sarcophagi, even imperfect ones, were in demand in Rome and vicinity is demonstrated by the extensive evidence regarding their reworking from previously-used examples and from blocks first used for other purposes.

\section{Appendix 1}

\section{The marble provenance of 20 Sarcophagi (27 samples) from the Museo Nazionale Romano.}

\section{Donato Attanasio}

The experimental results are given in Table 1 . The chest 222 and the chest 128581 were resampled (samples 5 and 14, respectively) in order to confirm the analyses. Average quarry data for the most relevant quarries are included at he end of Table 1. The assignments, however, were carried out using a more extensive selection of possible provenance sites (see the full list of quarries below).

The assignment has been carried out using simultaneously 6 experimental variables $^{88}$ :

2 isotopic:

$\delta^{18} \mathrm{O}\left(\right.$ delta Oxy- $\quad \delta^{13} \mathrm{C}($ delta Cargen 18) bon 13)

2 petrographic:

MGS (Maximum Grain Size), Colour

2 EPR (Electron Paramagnetic Resonance): Intensity (=INTENS), Linewidth $(=\mathrm{W})$

The site selection included 9 of the most likely quarry sites (15 groups, 852 samples):

Carrara, Hymettos, Pentelicon,

Paros (Marathi, Marathi lychnites, Chorodaki),

Thasos calcitic, Afyon (Bacakale, Röder II/V, Röder III/IV),

Ephesos (Kusini Tepe, Belevi, Aya Klikiri), Miletos, Proconnesos.

87 Ben Russell proposed such a premature use for another unfinished sarcophagus at the MNR, which had only received carved borders for the fronts of the chest and lid, along with the border for the clipeus portrait on the chest: email communication of May 21, 2009; and Musso, in Giuliano 1984, 246-247.

88 Separate isotopic/MGS or EPR/MGS assignments tend to misclassify Hymettos for Carrara or give uncertain Carrara provenances. 
Table 1

\begin{tabular}{|c|c|c|c|c|c|c|c|c|c|}
\hline No. & Label & Inv/Descr & $\delta^{18} \mathrm{O}$ & $\delta^{13} \mathrm{C}$ & dolom & Intens & W & Colour & MGS \\
\hline 1 & 1.26 & $\begin{array}{l}\text { Busts Selene, } \\
\text { Helios }\end{array}$ & -2.02 & 1.89 & 0.0 & 0.041 & 0.627 & 195 & 1.10 \\
\hline 2 & 2.14 & 121657, Chest & -1.70 & 1.94 & 0.0 & 0.424 & 0.588 & 193 & 0.45 \\
\hline 3 & 3.13 & 121657, Lid & -2.02 & 2.17 & 0.0 & 0.574 & 0.627 & 225 & 0.45 \\
\hline 4 & 4.12 & 222 chest & -4.72 & 2.71 & 0.0 & 9.84 & 0.854 & 204 & 0.65 \\
\hline 5 & 08.4 & 222 chest bis & -4.72 & 2.55 & 0.0 & 1.385 & 0.587 & 198 & 1.0 \\
\hline 6 & 5.4 & $\begin{array}{l}\text { 125891, Ulpia } \\
\text { Domina }\end{array}$ & -3.62 & 2.73 & 0.0 & 0.033 & 0.630 & 192 & 1.70 \\
\hline 7 & 6.7 & 128086 & -6.88 & 2.71 & 0.0 & 0.617 & 0.640 & 211 & 0.55 \\
\hline 8 & 7.9 & 56138 & -2.25 & 1.96 & 0.0 & 0.053 & 0.678 & 209 & 1.10 \\
\hline 9 & 8.8 & 72879 & -1.51 & 3.45 & 0.0 & 0.169 & 0.535 & 200 & 1.70 \\
\hline 10 & 9.5 & 124735 & -1.51 & 2.70 & 0.0 & 0.016 & 0.592 & 199 & 1.10 \\
\hline 11 & 10.11 & 407, Lid & -1.72 & 2.01 & 0.0 & 0.589 & 0.612 & 215 & 0.40 \\
\hline 12 & 11.10 & 407, Chest & -1.99 & 2.15 & 0.0 & 0.461 & 0.627 & 217 & 0.50 \\
\hline 13 & 12.3 & 128581, chest & -13.25 & 1.47 & 0.0 & 1.912 & 0.534 & 212 & 0.30 \\
\hline 14 & 08.3 & 128581 chest bis & -9.64 & 1.91 & 0.0 & 1.720 & 0.566 & 213 & 0.70 \\
\hline 15 & 08.2 & $128581 \mathrm{lid}$ & -1.89 & 2.10 & 0.0 & 0.617 & 0.680 & 214 & 0.55 \\
\hline 16 & 13.1 & 226119 & -2.41 & 3.06 & 0.0 & 0.027 & 0.601 & 188 & 1.60 \\
\hline 17 & 14.23 & 750 & -1.30 & 3.03 & 0.0 & 0.030 & 0.578 & 198 & 1.70 \\
\hline 18 & 15.16 & 126285 & -0.96 & 3.40 & 0.0 & 0.091 & 0.573 & 172 & 1.75 \\
\hline 19 & 16.17 & 524 & -1.74 & 3.17 & 0.0 & 0.041 & 0.668 & 224 & 1.40 \\
\hline 20 & 17.18 & $\begin{array}{l}\text { Endymion, dog, } \\
\text { erratic }\end{array}$ & -1.71 & 3.12 & 0.0 & 0.036 & 0.709 & 200 & 1.70 \\
\hline 21 & 18.21 & 115247, Chest & -1.29 & 2.03 & 0.0 & 0.979 & 0.576 & 221 & 1.10 \\
\hline 22 & 19.2 & 115247, Lid & -1.19 & 2.21 & 0.0 & 0.530 & 0.594 & 227 & 0.90 \\
\hline 23 & 20.22 & Lenos, Marsyas & -1.59 & 2.68 & 0.0 & 0.036 & 0.654 & 199 & 1.60 \\
\hline 24 & 21.24 & 654 & -4.71 & 2.81 & 0.17 & 3.814 & 0.734 & 202 & 0.90 \\
\hline 25 & 08.1 & $\begin{array}{l}\text { Cupid Psyche } \\
\text { pp. } 98-99\end{array}$ & -2.02 & 3.05 & 0.0 & 0.036 & 0.642 & 210 & 2.20 \\
\hline 26 & 08.6 & 75248 chest & -2.34 & 3.27 & 0.0 & 0.020 & 0.587 & 195 & 1.70 \\
\hline
\end{tabular}


Table 1 (Continued)

\begin{tabular}{|l|l|l|l|l|l|l|l|l|l|}
\hline No. & Label & Inv/Descr & $\boldsymbol{\delta}^{\mathbf{1 8}} \mathbf{O}$ & $\boldsymbol{\delta}^{\mathbf{1 3}} \mathbf{C}$ & dolom & Intens & $\mathbf{W}$ & Colour & MGS \\
\hline 27 & 08.5 & 75248 lid & -2.26 & 3.05 & 0.0 & 0.027 & 0.736 & 177 & 1.70 \\
\hline & $\mathrm{Ca}$ & & -1.89 & 2.11 & 0.01 & 0.685 & 0.634 & 211 & 0.80 \\
\hline & Afy & & -4.32 & 1.80 & 0.00 & 2.425 & 0.539 & 193 & 0.86 \\
\hline & $\mathrm{Hy}$ & & -2.17 & 2.20 & 0.03 & 0.142 & 0.460 & 182 & 0.69 \\
\hline & $\mathrm{Pe}$ & & -7.00 & 2.63 & 0.003 & 2.263 & 0.582 & 229 & 0.96 \\
\hline & $\mathrm{Pa}$ & & -1.11 & 1.79 & 0.04 & 0.195 & 0.479 & 214 & 2.07 \\
\hline & & & & & & & & \\
\hline & Th & & -0.73 & 2.98 & 0.006 & 1.308 & 0.557 & 201 & 3.84 \\
\hline
\end{tabular}

Using the 6 variables mentioned above, the rate of discrimination for the 15 marble groups is $83.7 \%$, or $82.9 \%$ after statistical validation. The results of the assignment for the 27 marble samples under investigation are summarized in Table 2 below:

Definitions of the probability parameters in Table 2

Relative (posterior) This is the probability that the sample belongs to some probability: group, assuming that it originates in any case from one of the groups in the selection. The threshold is $60 \%$. Low values indicate that the sample's assignment is in doubt between two or more groups.

Absolute (typical) This is a distance dependent parameter measuring the probability: absolute probability that the sample belongs to the chosen group or, in other words, is a typical representative of the group's properties. The threshold is $10 \%$, corresponding to samples on the edge of the $90 \%$ probability ellipse. Low values indicate anomalous samples (outliers) or samples possibly not belonging to any group in the selection.

Distance: This is the distance of a point under consideration from the center of the ellipse that represents the probability field of a quarry. The central point of an ellipse expresses the average and hence most characteristic values of a quarry. The closer a point under consideration is to the center of an ellipse, the more likely it is to be made of the marble represented by the ellipse. 
Table 2

\begin{tabular}{|l|l|l|l|l|l|l|l|}
\hline & Sample & Description & Isotopes & Sitel & $\begin{array}{l}\text { Relative } \\
\text { (posterior) } \\
\text { probability }\end{array}$ & $\begin{array}{l}\text { Absolute } \\
\text { (typical) } \\
\text { probability }\end{array}$ & Distance \\
\hline 1 & 1.26 & $\begin{array}{l}\text { Busts } \\
\text { Selene, } \\
\text { Helios }\end{array}$ & Ca & Pro & 77 & $\mathbf{5 2}$ & 5.0 \\
\hline 2 & 2.14 & $\begin{array}{l}121657, \\
\text { Chest }\end{array}$ & Ca & Ca & 91 & $\mathbf{5 3}$ & 5.1 \\
\hline 3 & 3.13 & 121657, Lid & Ca & Ca & 100 & $\mathbf{4 7}$ & 5.6 \\
\hline 4 & 4.12 & 222 chest & Afy & Afy & 56 & $\mathbf{1}$ & 17 \\
\hline 5 & 08.4 & $\begin{array}{l}222 \text { chest } \\
\text { bis }\end{array}$ & Afy & Afy & 90 & $\mathbf{7 5}$ & 3.4 \\
\hline 6 & 5.4 & $\begin{array}{l}125891, \\
\text { Ulpia } \\
\text { Domina }\end{array}$ & Pro & Pro & 93 & $\mathbf{8 8}$ & 2.4 \\
\hline 7 & 6.7 & 128086 & Pe & Pe & 98 & $\mathbf{2 8}$ & 7.5 \\
\hline 8 & 7.9 & 56138 & Hy & Pro & 71 & $\mathbf{3 2}$ & 7 \\
\hline 9 & 8.8 & 72879 & Pro & Pro & 39 & $\mathbf{2 1}$ & 8.4 \\
\hline 10 & 9.5 & 124735 & Pro & Pro & 99 & $\mathbf{5 3}$ & 5.1 \\
\hline 11 & 10.11 & 407, Lid & Ca & Ca & 99 & $\mathbf{3 3}$ & 6.9 \\
\hline 12 & 11.10 & 407, Chest & Ca & Ca & 89 & 77 & 3.3 \\
\hline 13 & 12.3 & $\begin{array}{l}128581, \\
\text { chest }\end{array}$ & ? & Pe & 100 & $\mathbf{0}$ & 52 \\
\hline 14 & 08.3 & $\begin{array}{l}128581 \\
\text { chest bis }\end{array}$ & $\sim$ Pe & Pe & 100 & $\mathbf{2 6}$ & 7.8 \\
\hline 15 & 08.2 & 128581 lid & & Ca & 100 & $\mathbf{9 4}$ & 1.8 \\
\hline 16 & 13.1 & 226119 & Pro & Pro & 98 & $\mathbf{9 6}$ & 1.5 \\
\hline 17 & 14.23 & 750 & Pro & Pro & 96 & $\mathbf{9 6}$ & 1.4 \\
\hline 18 & 15.16 & 126285 & Pro & Pro & 94 & $\mathbf{3 7}$ & 6.5 \\
\hline 19 & 16.17 & 524 & Pro & Pro & 96 & $\mathbf{6 0}$ & 4.6 \\
\hline 20 & 17.18 & $\begin{array}{l}\text { Endym., } \\
\text { dog, erratic }\end{array}$ & Pro & Pro & 99 & $\mathbf{5 9}$ & 4.6 \\
\hline 21 & 18.21 & $\begin{array}{l}115247, \\
\text { Chest }\end{array}$ & Cho & Ca & 93 & $\mathbf{8 2}$ & 2.9 \\
\hline
\end{tabular}


Table 2 (Continued)

\begin{tabular}{|l|l|l|l|l|l|l|l|}
\hline & Sample & Description & Isotopes & Site1 & $\begin{array}{l}\text { Relative } \\
\text { (posterior) } \\
\text { probability }\end{array}$ & $\begin{array}{l}\text { Absolute } \\
\text { (typical) } \\
\text { probability }\end{array}$ & Distance \\
\hline 22 & 19.2 & 115247, Lid & Pro & Ca & 97 & $\mathbf{9 7}$ & 1.3 \\
\hline 23 & 20.22 & $\begin{array}{l}\text { Lenos, } \\
\text { Marsyas }\end{array}$ & Pro & Pro & 96 & $\mathbf{9 0}$ & 2.2 \\
\hline 24 & 21.24 & 654 & Afy & Afy & 63 & $\mathbf{1 4}$ & 9.6 \\
\hline 25 & 08.1 & $\begin{array}{l}\text { Cupid } \\
\text { Pysche } \\
\text { pp. } 98-99\end{array}$ & Pro & Pro & 94 & 77 & 3.3 \\
\hline 26 & 08.6 & 75248 chest & Pro & Pro & 99 & & $\mathbf{8 5}$ \\
\hline 27 & 08.5 & 75248 lid & Pro & Pro & 100 & $\mathbf{2 2}$ & 8.3 \\
\hline
\end{tabular}

\section{Comments:}

25 different pieces were sampled and analysed. Two chests, however (nos. 4 and 13), needed to be verified and were resampled (samples 5 and 14). For this reason, Tables 1 and 2 contain data for 27 samples.

5 sarcophagi provided samples from both the chest and the lid (121657, 407, 128581, 115247, and 75248). 4 of them turned out to be made of the same marble (Carrara for 121657, 407, and 115247; Proconnesos for 75248). The last sarcophagus (128581), however, was manufactured using different marbles: Carrara for the lid and Pentelicon for the chest.

13 chest samples $(1,6,8,9,10,16,17,18,19,20,23,25,26)$ and 1 lid sample (27) are very low in EPR intensity $(\leq 0.1)$ and medium $(\sim 1.1-1.7 \mathrm{~mm})$ grained. In agreement with isotopes and other properties, they are all assigned to Proconnesos.

3 chest samples $(2,12,21)$ and 4 lid samples $(3,11,15,22)$ exhibit medium EPR intensity $(-0.5)$. The grain size is generally fine, although sample 18 has a MGS $=1.1 \mathrm{~mm}$. In agreement with isotopes and other properties, they are all assigned to Carrara.

2 chest samples (7 and 13/14) are assigned as Pentelicon. Sample 13 shows an extremely negative $\delta^{18} \mathrm{O}(-13.25)$. Resampling has given -9.64 . The Pentelicon assignment has been confirmed and improved.

2 chest samples $(4 / 5,24)$ require some further comment. In statistical terms, the most probable provenance site is certainly Afyon in both cases. Pentelicon, however, represents a reasonable alternative, with the probability values being only slightly smaller. The presence in both marbles of numerous micaceous inclusions indicates unambiguously that Pentelicon is, in fact, the true 
provenance of both samples. Note that in this case resampling and retesting of sample 4 (sample 5) was not helpful.

The final distribution of the 25 pieces ( 20 chests, 5 lids) is:

Proconnesos 13 chests 1 lid 14 total samples $56 \%$

Carrara 3 chests 4 lids 7 total samples $28 \%$

Pentelicon 4 chests 0 lids 4 total samples $16 \%$

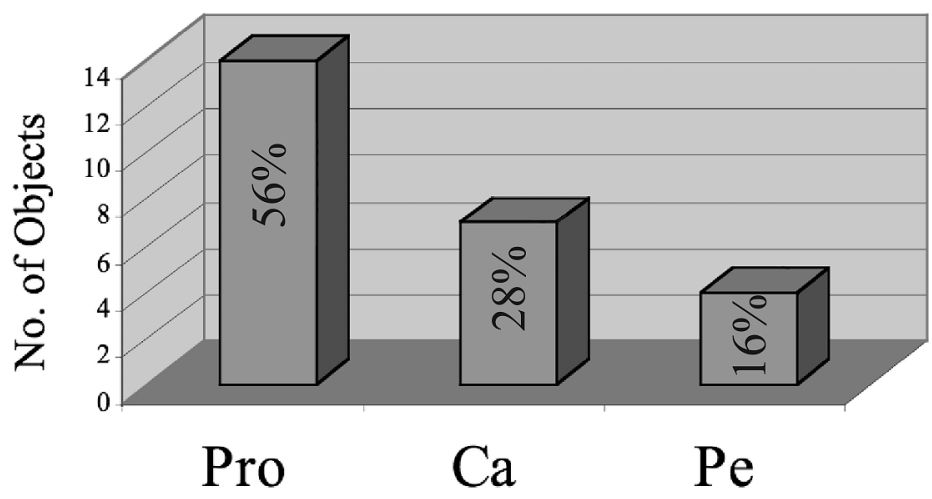

Graph 1

Original and expanded isotopic graphs

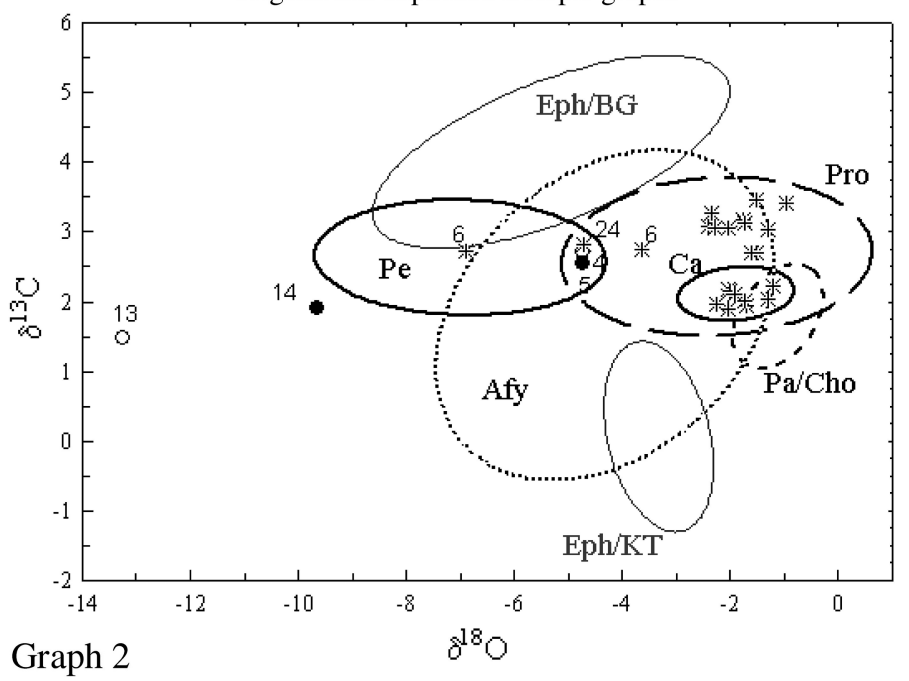




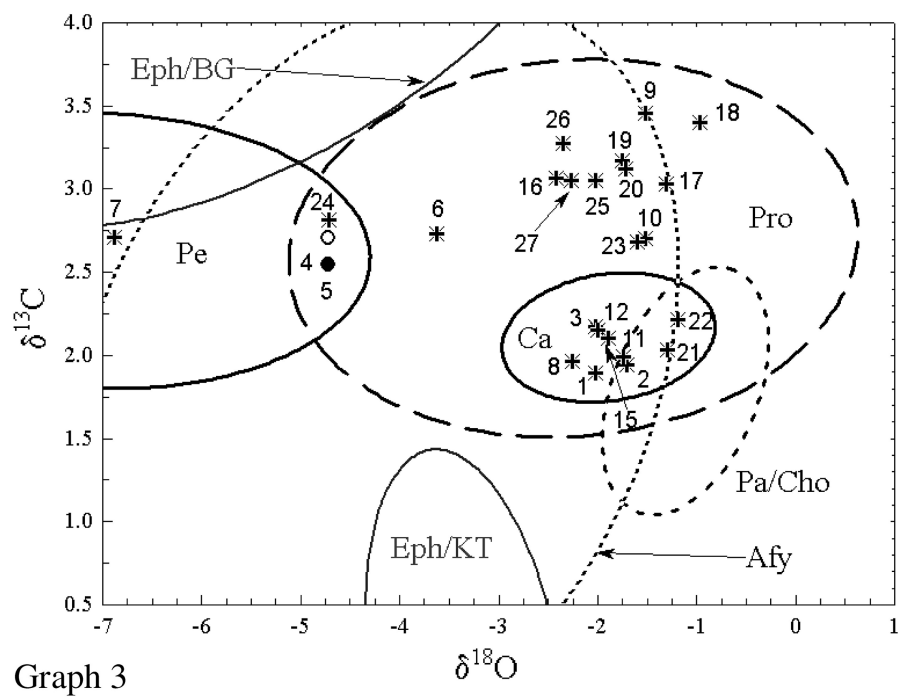

EPR log graph (intensity vs. line width)

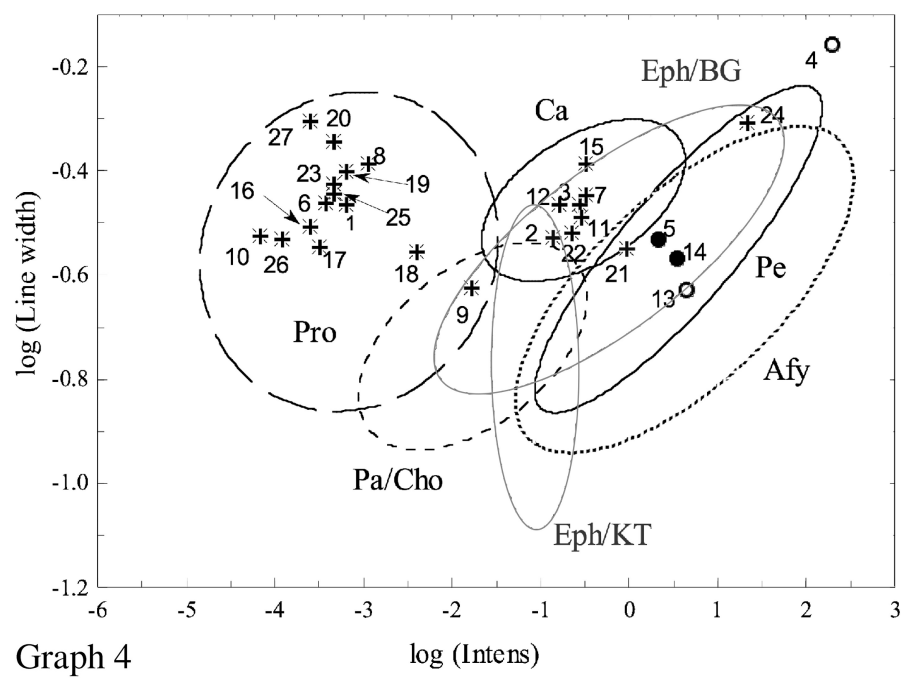


Statistical plots.

Discr.Coord. $1=0.82 \times$ Intensity $+0.64 \times \delta^{18} \mathrm{O}+$ minor contributions

Discr.Coord. $2=0.88 \times$ MGS $+0.53 \times$ Intensity + minor contributions

Discr.Coord. $3=0.71 \times \delta^{13} \mathrm{C}+0.63 \times \delta^{18} \mathrm{O}+$ minor contributions

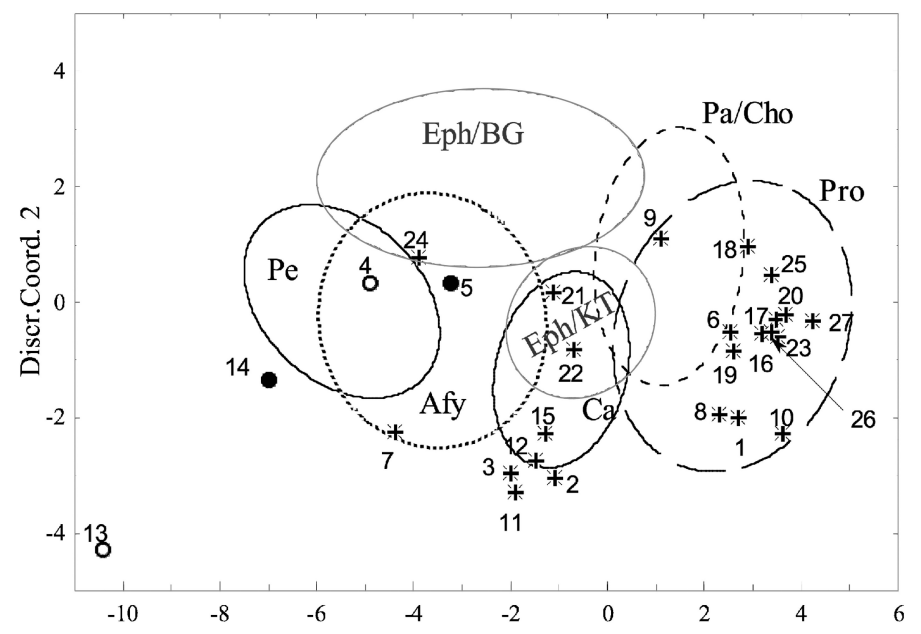

Graph 5

Discr.Coord. 1

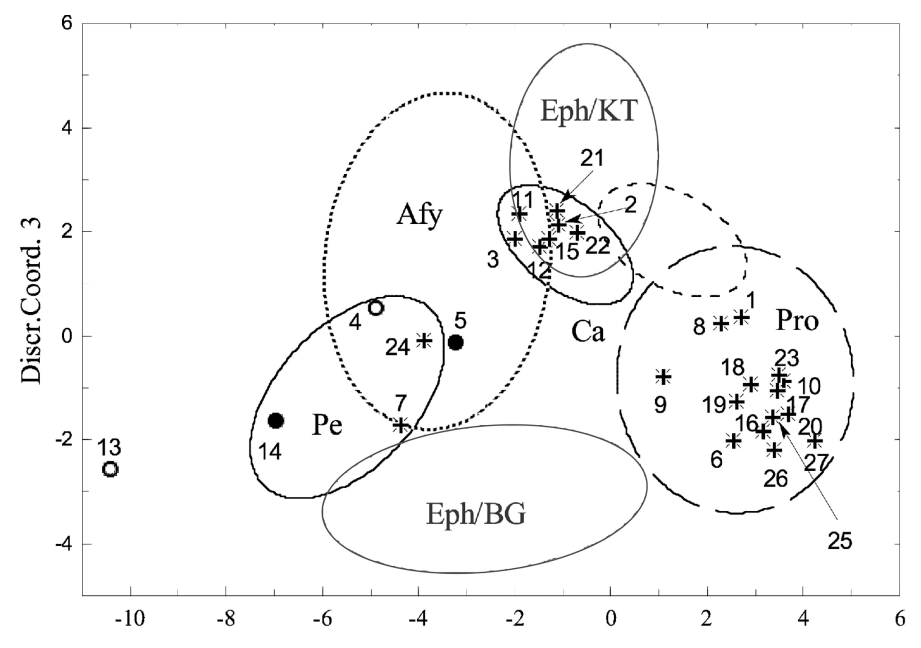

Graph 6

Discr.Coord. 1 


\section{Appendix 2 \\ Sarcophagi Made from Reused Architectural Blocks in the Fourth Century}

John J. Herrmann, Jr.

This program of scientific testing in the Museo Nazionale Romano has identified Carrara marble in two sarcophagi of the fourth century. At least one of them seems to have been made from an old block previously employed for a different purpose. The back side of the Carrara marble strigillated sarcophagus with a bust of a youth in a clipeus has several features that seem in no way related to the funerary function of the piece (see Figures 5.5-5.6). A long diagonal line divides the backside into upper and lower fields that have different kinds of tool marks. The marks of a pointed chisel in the upper field are sharp and clear. The lower field, on the other hand, has an amorphous surface that suggests the passage of water. Peg holes in the upper field seem unrelated to any possible use as a sarcophagus. While no specific function for these features can be suggested, they make it clear that the block had gone through one or two previous phases of use before taking its present form.

The other fourth-century Carrara sarcophagus also has anomalous features that could well be due to reuse of a pre-existing block (Figure 5.2). On the lower part of its left end are two long, well patinated troughs for iron clamps. This ancient repair was intended to fasten a slab of marble along the lower front of the sarcophagus. It seems likely that this expedient was intended to compensate for an imperfection in the block - perhaps damage from a previous use.

Examination of the chests of Early Christian sarcophagi in the Vatican's Museo Pio Cristiano Lateranense makes it clear that at least some fourthcentury sarcophagi were made of reused blocks originally intended for large public buildings. ${ }^{89}$ A sarcophagus with the twelve Apostles ${ }^{90}$ has a plain ovolo moulding along the lower edge of the back; such a profile betrays a former use or intended use as a cornice in a major colonnade. A column sarcophagus ${ }^{91}$ has a plain ovolo and cavetto along its lower rear edge. Another column sarcophagus has a plain cyma reversa along the lower edge of its back. ${ }^{22}$ Two more sarcophagi - a Crossing of the Red Sea ${ }^{93}$ and a strigillated sarcophagus with an Orans ${ }^{94}$

89 See also Herrmann 2009, 124.

90 Rep. I, cat. no. 65 (inv. 31521); Hourihane, system no. 000181933.

91 Rep. I, cat. no. 53 (inv. 31475); Hourihane, system no. 000102362.

92 Rep. I, cat. no. 52 (inv. 31489); Hourihane, system no. 000103395.

93 The mouldings are simple cavettos. Rep. I, cat. no. 64 (without new inventory number); Hourihane, system no. 000103943.

94 Rep. I, cat. no. 73 (inv. 31452); Hourihane, system no. 000102000. 
have narrow architectural mouldings on their ends. All five of these blocks must also have come from dismantled or unfinished public buildings. ${ }^{95}$ The marble of these chests has not been tested, but optically it seems to include both finegrained white, grey-spotted marble and grey-banded coarser grained marble. Hence it is likely that buildings made of both Cararra and Proconnesian marble provided marble for the sarcophagi.

A frieze sarcophagus of Roman type in the Archaeological Museum, Split, Croatia also has an architectural moulding - a plain cyma recta and two fillets along its lower rear edge, as pointed out by Guntram Koch. ${ }^{96}$ The sarcophagus shows the Israelites crossing the Red Sea on its front, and three figures separated by strigillated panels on its reverse. ${ }^{97}$ All the figural work dates from the late fourth century, and only the moulding reflects the block's previous architectural use.

It should be noted that all these mouldings are in concealed places on the sarcophagi. They appear on undecorated sides or backs of the chests and are not used decoratively themselves. When the mouldings appear on the short sides of the chests, they are simple, low, and hardly visible on the decorated front. Modern photographers tend to minimize them or avoid them altogether. All the mouldings are schematic; they are not finished as an egg-and-dart or as a Lesbian cymation.

The fact that private individuals could have access to these blocks connected with major public buildings is to some degree surprising from a legal point of view. Patrizio Pensabene has emphasized that imperial legislation in the fourth century tended to restrict private access to marble from public buildings. $\mathrm{He}$ has, however, suggested that some reused material could have come from deposits connected with unfinished buildings, ${ }^{98}$ and this may well have been the source for the large blocks with unfinished mouldings used for these sarcophagi.

By themselves the five chests in the Museo Pio Cristiano with architectural mouldings represent a significant proportion of the 26 well-preserved sarcophagi in the collection. There are, in addition, various less conspicuous indications that marble was reused for other sarcophagi in the Museo Pio Cristiano. Seven other chests were put together from various pieces rather than carved from single blocks. The joints between pieces are sharp, straight cuts. ${ }^{99}$

95 The lid of a frieze sarcophagus also has a sima profile on its rear edge: Rep. I, cat. no. 6 (inv. 31509); Spinola 2000b; Hourihane, system no. 000102367.

96 We discussed the issue of fresh versus reused blocks at the Archaeological Museum, Split, on June 8, 2007.

97 Rep. II, cat. no. 146; Hourihane, system no. 000098149.

98 Pensabene, in Pensabene and Panella 1993-1994, 128-130.

99 Rep. I, cat. nos. 2 (inv. 31485); 7 (inv. 31440); 49 (inv. 31525); 61 (inv. 28591); 74 (inv. 31407); and 29 (inv. 31554); Hourihane, respectively, system nos. 000101953, 000102360, 000102608, 000102535, 000182033, and 000102188. The fourth 
This kind of patchwork is not seen in sarcophagi from earlier centuries and again suggests that the blocks were salvaged marble rather than freshly quarried. As noted above, a Carrara marble sarcophagus in the Museo Nazionale Romano provides a discreet instance of this kind of piecing (Figure 5.2). Giandomenico Spinola has argued that a joint in one of the Vatican sarcophagi is due to considerations of display, ${ }^{100}$ but other sarcophagi in the collection make it clear that the cuts are not modern, since the pieces to be attached are missing. This is particularly evident in the case of a strigillated sarcophagus with a learned lady at the centre and a shepherd at the right end; the sarcophagus lacks the figural panel at the left end that should have abutted the vertical edge of the left-hand panel of strigillations. ${ }^{101}$

Some of the remaining 14 sarcophagi in the Museo Pio Cristiano revealed other anomalies, such as different kinds of tooling on the back and sides. An alternation of pointed, flat, and claw chisels on the different sides might well be indications that the blocks were reused.

Several fourth-century chests, on the other hand, lacked any such anomalies and in all probability were sculpted from newly quarried blocks. Three massive sarcophagi stood out for their regularity of shape and consistency of workmanship: the 'Dogmatic' sarcophagus, ${ }^{102}$ the 'Ludovisi' sarcophagus, ${ }^{103}$ and a strigillated sarcophagus centred on the Denial of Peter. ${ }^{104}$ They are prime candidates for being new production, and, it might be added, all three present the medium or coarse grain and dark grey stripes of Proconnesian marble. Several smaller sarcophagi, which also seemed to be Proconnesian marble, again lacked anomalies. The sarcophagi of Sabinus ${ }^{105}$ and of Priscus ${ }^{106}$ date from the fourth century. Four other apparently Proconnesian chests date from the second half of the third century or the beginning of the fourth: a child's strigillated sarcophagus, ${ }^{107}$ a pastoral sarcophagus, ${ }^{108}$ the sarcophagus from the Via Salaria, ${ }^{109}$ and that of Aurelia Severa. ${ }^{10}$

sarcophagus is also Spinola 2000a. Also a sarcophagus with Seasons and an Orans, inv. 31425 (not in Rep. I).

100 Spinola 2000a.

101 Rep. I, cat. no. 74 (inv. 31407); Hourihane, system no. 000182033. In recent years the reconstructed left panel has been removed, revealing the smooth surface of the joint.

102 Rep. I, cat. no. 43 (inv. 31427); Hourihane, system no. 000101998.

103 Rep. I, cat. no. 86 (inv. 31408); Hourihane, system no. 000102544.

104 Rep. I, cat. no. 77 (inv. 31495); Hourihane, system no. 000102309.

105 Rep. I, cat. no. 6 (inv. 31509); Spinola 2000b; Hourihane, system no. 000102367.

106 inv. 31592; without figures.

107 inv. 31419; non-Christian.

108 Rep. I, cat. no. 32 (inv. 31465); Hourihane, system no. 000102370.

109 Rep. I, cat. no. 66 (inv. 31540); Hourihane, system no. 000099487.

110 inv. 30932; without figures. 
A rapid review of the Vatican's collection of Christian sarcophagi then demonstrates that certainly some, and possibly a very substantial part of the collection and, by extension, of fourth century sarcophagi in Rome in general were made of previously quarried marble blocks. The phenomenon of scavenged marble is difficult to detect in most cases since the sculptors seem to have wanted to conceal anomalies, which apparently would have detracted from the ideological messages they wished to project. The reuse of blocks for sarcophagi in the fourth century is not entirely surprising, given that so much of the marble used in the architecture of the period in Rome was reused, but, as noted above, the availability of massive architectural blocks for private use represents something of a novelty. It is less surprising that some newly quarried marble blocks for sarcophagi would have come from the Proconnesos, the source of most of the marble for Constantinople, the new and rapidly expanding capital city of the Empire, and a great exporter to other parts of the Empire, including fourth-century Rome. ${ }^{111}$ The question now remains, what portion of the Proconnesian marble sarcophagi at Rome was made of reused marble. Even more intriguing is the question of whether any of the marble from other quarries used for Roman sarcophagi in the fourth century was fresh production. In particular, activity in the quarries of Carrara (ancient Luna) remains a major unknown. Based on the sarcophagi in the Museo Pio Cristiano and the tested sarcophagi in the Museo Nazionale Romano, it seems possible that blocks for sarcophagi may not have been produced in Carrara during the fourth century.

\section{Acknowledgements}

Dr. Maria Antonietta Tomei, Director of the Museo Nazionale Romano in the Baths of Diocletian, most generously granted permission for samples to be taken from the 20 sarcophagi at her museum. Funding support for the analyses was provided by the Writing Intensive Fellows Program, the University of Georgia, and the Lamar Dodd School of Art, the University of Georgia. The Samuel H. Kress Foundation in New York provided funds for Prof. Frances Van Keuren and three of the four University of Georgia students who worked on the 20 sarcophagi in her fall 2007 seminar - Chad Alligood, Maria Graffagnino, Soon Bae Kim, and Katie Seefeldt - to travel to Rome in March 2008 and study and photograph the sarcophagi, and to meet with Dr. Donato Attanasio in his lab. These students' most significant contributions are recognised in the footnotes. Prof. Van Keuren's husband Lenny Valliere, chemist at Coca Cola in

111 For Proconnesian capitals and column shafts at Rome, see Pensabene 1973, cat. nos. 383-384; Herrmann 1988, pp. 94-96, 154, 180 (B), figs. 173, 176, 318-319; Kramer 1997; Pensabene, in Pensabene and Panella 1993-1994, p. 142; Pensabene et al. 1999. 
Atlanta, provided invaluable help with the discussion of the analytical techniques in the first part of the article. Mary Emerson, Associate Lecturer at the Open University, Milton Keynes, England, looked at the sarcophagi at the Museo Nazionale Romano with Prof. Van Keuren, and offered many important insights. Finally, Dr. Janet Huskinson was most helpful, flexible and patient during the difficult preparation of this collaborative article.

\section{Bibliography}

Alessio, A. and Zaccaria, A. Nuove ricerche sul relitto di San Pietro in Bevanga (Manduria -Taranto), in: G. Volpe (ed.), Atti del convegno nazionale di archeologia subacquea. Anzio, 30-31 maggio e 1 giugno 1996 (Bari, 1997), 211-224.

Amadori, M. L., Lazzarini, L., Mariottini, M., Pecoraro, M. and Pensabene, P. Determinazione della provenienza dei marmi usati per alcuni monumenti antichi di Roma, in: Marmi antichi II: Cave e tecnica di lavorazione, provenienze e distribuzione, edited by P. Pensabene (Rome, 1998), 45-55.

Andreae, B. The Art of Rome (New York, 1977).

Angeli, S. de. Demeter/Ceres, in: LIMC vol. 4 (Zürich and Munich, 1988), 893-908.

Aravantinos, B. Sarcofagi di Ostia. Archeologia Classica 59, n.s. 9 (2008), 147-182.

Attanasio, D. Ancient White Marbles: Analysis and Identification by Paramagnetic Resonance Spectroscopy (Rome, 2003).

Attanasio, D., Brilli, M. and Ogle, N. The Isotopic Signatures of Classical Marbles (Rome, 2006).

Attanasio, D., Brilli, M. and Bruno, M. The Properties and Identification of Marble from Proconnesos (Marmara Island, Turkey): A New Database Including Isotopic, EPR and Petrographic Data. Archaeometry 50.5 (2008), 747-774.

Baratte, F. and Metzger, C. Musée du Louvre: Catalogue des sarcophages en pierre d'époques romaine et paléochrétienne (Paris, 1985).

Bartman, E. Carving the Badminton Sarcophagus. Metropolitan Museum Journal 28 (1993), 57-75.

Bartoli, A. Marsia e Apollo sul Palatino. Bollettino d'Arte, ser. 4, vol. 38 (1953), 1-8. Berger-Doer, G. Kreousa II, in: LIMC, vol. 6 (Zürich and Munich, 1992), 120-127.

Bini, M., Chelli, A. and Pappalardo, M. Geomorfologia del territorio dell'antica Luni (La Spezia) per la ricostruzione del paesaggio costiero in età romana. Atti della Società Toscana di Scienze Naturali residente in Pisa. Memorie. Serie A, vol. 111 (2006), 57-66.

Blanc, N. and Gury, F. Eros/Amor, Cupido, in: LIMC, vol. 3 (Zürich and Munich, 1986), $952-1049$.

Blome, P. Zum Umgestaltung griechischer Mythen in der römischen Sepulkralkunst. Alkestis-, Protesilaos- und Proserpinasarkophage. Mitteilungen des Deutschen Archaeologischen Instituts. Roemische Abteilung 85 (1978), 435-457.

Bruno, M., Cancelliere, S., Gorgoni, C., Lazzarini, L., Pallante, P. and Pesabene, P. Provenance and distribution of white marbles in temples and public buildings of Imperial Rome, in: J. J. Herrmann, Jr., N. Herz, and R. Newman (eds.), ASMOSIA 5: Interdisciplinary Studies of Ancient Stone, Proceedings of the Fifth International Conference of the Association for the Study of Marble and Other Stones in Antiquity, Museum of Fine Arts, Boston, June 1998 (London, 2002), 289-300. 
Calia, A., Giannotta, M.T., Lazzarini, L. and Quarta, G. The Torre Sgarrata Wreck: Characterization and Provenance of White marble Artefacts in the Cargo, in: Y. Maniatis (ed.), ASMOSIA VII: Actes du VIIe colloque international de l'ASMOSIA Thasos 15-20 septembre 2003, Bulletin de Correspondance Hellénique Supplément 51 (Athens, 2009), 333-342.

Corcoran, S. and DeLaine, J. The unit measurement of marble in Diocletian's Prices Edict. Journal of Roman Archaeology 7 (1994), 263-273.

De Angelis d'Ossat, M. (ed.). Scultura antica in Palazzo Altemps, Museo Nazionale Romano (Milan, 2002).

Dodge, H. and Ward-Perkins, B. (eds.). Marble in antiquity: collected papers of J. B. Ward-Perkins (London, 1972).

Fant, J.C. Rome's marble yards. Journal of Roman Archaeology 14 (2001), 167-198.

Fazzini, P. and Maffei, M. The disappearance of the city of Luni. Journal of Cultural Heritage 1 (2000), 247-260.

Felletti Maj, B.M. Roma (Via Fezzan, Quartiere Nomentano). Rinvenimento di un sarcofago. Notizie degli scavi di antichità ser. 8, vol. 7 (1953), 234-235.

Floriani Squarciapino, M. Pannelli decorativi del tempio di Venere Genitrice. Atti della Accademia Nazionale dei Lincei. Memorie ser. 8, vol. 2 (1950), 61-118.

Gabellone, F., Giannotta, M.T. and Alessio, A. The Torre Sgarrata Wreck (South Italy): Marble Artefacts in the Cargo, in: Y. Maniatis (ed.), ASMOSIA VII: Actes du VIIe colloque international de l'ASMOSIA Thasos 15-20 septembre 2003, Bulletin de Correspondance Hellénique Supplément 51 (Athens, 2009), 319-331.

Gaggadis-Robin, V. Jason et Médée sur les sarcophages d'époque impériale (École Française de Rome, 1994), 'Collection de l'École Française de Rome' 191.

Gasparri, C. Dionysos/Bacchus, in: LIMC, vol. 3 (Zürich and Munich, 1986), 540566.

Giuliano, A. (ed.). Museo Nazionale Romano: Le Sculture, vol. I.2 (Rome, 1981).

Giuliano, A. (ed.). Museo Nazionale Romano: Le Sculture, vol. I.3 (Rome, 1982).

Giuliano, A. (ed.). Museo Nazionale Romano: Le Sculture, vol. I.7.2 (Rome, 1984).

Giuliano, A. (ed.). Museo Nazionale Romano: Le Sculture, vol. I.8, part 1 (Rome, 1985).

Gnoli, R. Marmora romana (Rome, 1971).

Gury, F. Selene/Luna, in: LIMC, vol. 7 (Zürich and Munich, 1994), 706-715.

Herrmann, J., Jr. and Newman, R. The exportation of dolomitic sculptural marble from Thasos: evidence from Mediterranean and other collections, in: Y. Maniatis, N. Herz and Y. Basiakos (eds.), ASMOSIA III Athens: Transactions of the $3^{\text {rd }}$ International Symposium of the Association of the Study of Marble and Other Stones used in Antiquity, Athens 17-19 May 1993 (London, 1995), 73-86.

Herrmann, J., Jr. and Newman, R. Dolomitic Marble from Thasos Near and Far: Macedonia, Ephesos and the Rhone, in: M. Schvoerer (ed.), Archéomatériaux: Marbres et autres roches. ASMOSIA IV, Bordeaux-Talence 9-13 octobre 1995 (London, 1999), 293-303.

Herrmann, J. J., Jr. The Ionic Capital in Late Antique Rome (Rome, 1988).

Herrmann, J. J., Jr. The Exportation of Dolomitic Marble from Thasos: A Short Overview, in: Thasos: Matières premières et technologie de la préhistoire à nos jours, Actes du Colloque International 26-29/9/1995, Thasos, Liménaria (Athens, 1999), 57-69.

Herrmann, J. J., Jr. Christian Sarcophagi of Reused Marble in the Vatican, in: IX ASMOSIA International Conference: Interdisciplinary Studies on Ancient Stone, Tarragona, 8-13 June 2009 (Association for the Study of Marbles and Other Stones in Antiquity and Institut Catala d'Arqueologia Classica), 124. 
Herrmann, J., Jr. Moens, L. and De Paepe, P. Some Identifications of Sculptures in Parian Marble in Boston, in: D.U. Schilardi and D. Katsonopoulou (eds.), Paria Lithos: Parian Quarries, Marble and Workshops of Sculpture. Proceedings of the First International Conference on the Archaeology of Paros and Cyclades, Paros, 2-5 October 1997 (Athens, 2000), 253-265.

Herz, N. Classical Marble Quarries of Thasos, in: Antike Edel- und Buntmetallgewinnung auf Thasos, edited by G.A. Wagner and G. Weisgerber (Bochum, 1988), 231 244.

Herz, N, and Garrison, E.G. Geological Methods for Archaeology (New York and Oxford, 1998).

Hesberg, H. von, Archäologische Denkmäler zu den römischen Göttergestalten. Aufstieg und Niedergang der römischen Welt II 17.2 (1981), 1032-1099.

Honroth, M. Stadtrömische Girlanden: Ein Versuch zur Entwicklungsgeschichte römischer Ornamentik. Sonderschriften hrsg. vom Österreichischen Archäologischen Institut in Wien, vol. 17. (Wien, 1971).

Hourihane, C. (director), Index of Christian Art (Princeton, ongoing, http://ica.princeton.edu/).

Huskinson, J. Roman Children's Sarcophagi: Their Decoration and its Social Significance (Oxford, 1996).

Knudsen, S.E., Craine, C. and Tykot, R.H. Analysis of classical marble sculptures in the Toledo Museum of Art, in: J. Herrmann, N. Herz, and R. Newman (eds.), ASMOSIA 5: Interdisciplinary Studies of Ancient Stone, Proceedings of the Fifth International Conference of the Association for the Study of Marble and Other Stones in Antiquity, Museum of Fine Arts, Boston, June 1998 (London, 2002), 231-239.

Koch, G. and Sichtermann, H. Römische Sarkophage. Handbuch der Archäologie (Munich, 1982).

Kramer, J. Spätantike korinthische Säulenkapitelle in Rom (Wiesbaden, 1997).

Lauffer, S. Diokletians Preisedikt. Texte und Kommentare: Eine altertumswissenschaftliche Reihe, vol. 5 (Berlin, 1971).

Letta, C. Helios/Sol, in: LIMC, vol. 4 (Zürich and Munich, 1988), 592-625.

Maischberger, M. Marmor in Rom: Anlieferung, Lager- und Werkplätze in der Kaiserzeit. Palilia, vol. 1 (Wiesbaden, 1997).

Mancini, G. Roma. Nuove scoperte di antichità in città e nel suburbio. Notizie degli scavi di antichità ser. 5, vol. 10 (1913), 116-120.

McCann, A.M. Roman Sarcophagi in The Metropolitan Museum of Art (New York, 1978).

Pensabene, P. I capitelli (Scavi di Ostia VII) (Rome, 1973).

Pensabene, P. and Panella, C. Reimpiego e progettazione architettonica nei monumenti tardo-antichi di Roma. Rendiconti della Pontificia Accademia Romana di Archeologia 66 (1993-1994), 111-283.

Pensabene, P., Semeraro, T., Lazzarini, L., Turi, B., and Soligo, M. The provenance of the marbles from the depository of the Temple of the Fabri Navales at Ostia, in: M. Schvoerer (ed.), Archéomatériaux: Marbres et autres roches. ASMOSIA IV, BordeauxTalence 9-13 octobre 1995 (London, 1999), 147-156.

Pensabene, P., Lazzarini, L., Soligo, M., Bruno, M., and Turi, B. The Parian Marble Blocks of the Fossa Traiana, in: D.U. Schilardi and D. Katsonopoulou (eds.), Paria Lithos: Parian Quarries, Marble and Workshops of Sculpture. Proceedings of the First International Conference on the Archaeology of Paros and Cyclades, Paros, 2-5 October 1997 (Athens, 2000), 527-536. 
Pietrogrande, A.L. Roma. Reg. VI. Ruderi e sarcofagi scoperti sulla via di Decima. Notizie degli scavi di antichità ser. 6, vol. 10 (1934), 155-168.

Pike, S. Archaeological Geology and Geochemistry of Pentelic Marble, Mount Pentelikon, Attica, Greece (unpublished Diss., University of Georgia, 2000).

Pingitore, N.E. The Behavior of $\mathrm{Zn}^{2+}$ and $\mathrm{Mn}^{2+}$ during Carbonate Diagenesis: Theory and Applications. Journal of Sedimentary Petrology 48.3 (September 1978), 799814.

Rawson, P.B. The Myth of Marsyas in the Roman Visual Arts: An Iconographic Study. BAR International Series 347 (Oxford, 1987).

Roueché, C., with contributions by J.M. Reynolds. Aphrodisias in Late Antiquity: The Late Roman and Byzantine Inscriptions including Texts from the Excavations at Aphrodisas conducted by Kenan T. Erim. Journal of Roman Studies Monograph 5 (London, 1989).

Sande, S. The Myth of Marsyas: Pieces of a Sculptural Jigsaw. Metropolitan Museum Journal 16 (1981), 55-73.

Santolini, R. Sarcofago a lenòs strigilato con Helios e Selene entro clipei. Notizie degli scavi di antichità ser. 8, vol. 40-41 (1986-87), 130-134.

Schauenburg, K. Ganymed und Hahnenkämpfe auf römischen Sarkophagen. Archäologischer Anzeiger (1972), 501-516.

Schmidt, M. Der Basler Medeasarkophag; ein Meisterwerk spätantoninischer Kunst (Tübingen, 1968).

Schmidt, M. Medeia, in: LIMC, vol. 6 (Zürich and Munich, 1992), 386-398.

Sengelin, T. Kentauroi et Kentaurides, in: LIMC, vol. 8 (Zürich and Munich, 1997), $671-721$.

Sichtermann, H. Sarkophag-Miszellen: Fragmente. Archäologischer Anzeiger (1974), $308-323$.

Spinola, G. cat. no. 48, in: Pietro e Paolo: La storia, il culto, la memoria nei primi secoli, edited by A. Donati (Milan, 2000a), 126 and 207-208.

Spinola, G., cat. no. 50, in: Pietro e Paolo: La storia, il culto, la memoria nei primi secoli, edited by A. Donati (Milan, 2000b), 129 and 208-210.

Throckmorton, P. The Ship of Torre Sgarrata, in: H. Tzalas (ed.), Tropis I. 1st International Symposium on Ship Construction in Antiquity: proceedings (Athens, 1989), 263-274.

Tykot, R.H., Herrmann, J.J., Jr., van der Merwe, N.J, Newman, R. and Allegretto, K.O. Thasian marble sculptures in European and American collections: isotopic and other analyses, in: J.J. Herrmann, Jr., N. Herz, and R. Newman (eds.), ASMOSIA 5: Interdisciplinary Studies of Ancient Stone, Proceedings of the Fifth International Conference of the Association for the Study of Marble and Other Stones in Antiquity, Museum of Fine Arts, Boston, June 1998 (London, 2002), 188-195.

Tykot, R.H. Scientific methods and applications to archaeological provenance studies, in: M. Martini, M. Milazzo and M. Piacentini (eds.), Proceedings of the International School of Physics 'Enrico Fermi' Course CLIV (Amsterdam, 2004), 407-432.

Van Keuren, F., with contributions by L. Peter Gromet. The Marbles of Three Mythological Sarcophagi at RISD and of Other Sarcophagi Found in Central Italy, in: KOINE: Mediterranean Studies in Honor of R. Ross Holloway, edited by D.B. Counts and A. Tuck (Oxford, 2009), 187-206.

Vian, F. and Moore, M.B. Gigantes, in: LIMC, vol. 4 (Zürich and Munich, 1988), $191-270$.

Visconti, C.L. Delle pitture murali di tre sepolcri ostiensi discoperti nel MDCCCLXV. Annali dell'Instituto di Corrispondenza Archeologica 38 (1866), 292-325. 
Walker, S. The Marble Quarries of Proconnesos: Isotopic Evidence for the Age of the Quarries and for Lenos-Sarcophagi Carved at Rome, in: Marmi antichi: Problemi d’impiego, di restauro e d'identificazione, edited by P. Pensabene (Rome, 1985), 57 65.

Walker, S. Aspects of Roman Funerary Art, in: Image and Mystery in the Roman World: Three papers given in memory of Jocelyn Toynbee, edited by J. Huskinson, M. Beard and J. Reynolds (Gloucester, 1988a), 23-36.

Walker, S. From West to East: Evidence for a Shift in the Balance of Trade in White Marbles, in: N. Herz and M. Waelkens (eds.), Classical Marble: Geochemistry, Technology, Trade. Proceedings of the NATO Advanced Research Workshop on Marble in Ancient Greece and Rome: Geology, Quarries, Commerce, Artifacts. Il Ciocco, Lucca, Italy. May 9-13, 1988. NATO ASI Series E: Applied Sciences, vol. 153 (Dordrecht, 1988b), 187-195.

Walker, S. and Matthews, K. Recent Work on Stable Isotope Analysis of White Marble at the British Museum, in: J.C. Fant (ed.), Ancient Marble Quarrying and Trade: Papers from a Colloquium held at the Annual Meeting of the Archaeological Institute of America, San Antonio, Texas, December, 1986. BAR International Series 453 (1988), $117-125$.

Ward-Perkins, J.B. and Throckmorton, P. The San Pietro Wreck. Archaeology 18 (1965), $201-209$.

Woodford, S. Meleagros, in: LIMC, vol. 6 (Zürich and Munich, 1992), 414-435.

Wurch-Kozelj, M. and Kozelj, T. Roman quarries of Apse-Sarcophagi in Thassos of the second and third centuries, in: Y. Maniatis, N. Herz and Y. Basiakos (eds.), ASMOSIA III Athens: Transactions of the $3^{\text {rd }}$ International Symposium of the Association of the Study of Marble and Other Stones used in Antiquity, Athens 17-19 May 1993 (London, 1995), 39-47 
